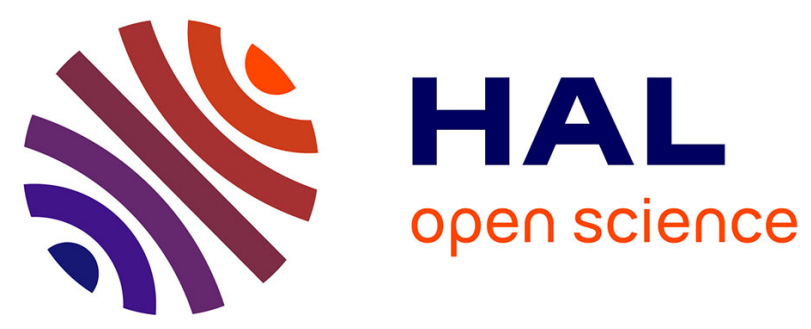

\title{
Eggshell matrix proteins OC-116, OC-17 and OCX36 in hen's sperm storage tubules
}

\author{
Cindy Riou, Luiz-Augusto Cordeiro, Nadine Gérard
}

\section{To cite this version:}

Cindy Riou, Luiz-Augusto Cordeiro, Nadine Gérard. Eggshell matrix proteins OC-116, OC-17 and OCX36 in hen's sperm storage tubules. Animal Reproduction Science, 2017, 185. hal-01602692

\section{HAL Id: hal-01602692 \\ https://hal.science/hal-01602692}

Submitted on 25 May 2020

HAL is a multi-disciplinary open access archive for the deposit and dissemination of scientific research documents, whether they are published or not. The documents may come from teaching and research institutions in France or abroad, or from public or private research centers.
L'archive ouverte pluridisciplinaire HAL, est destinée au dépôt et à la diffusion de documents scientifiques de niveau recherche, publiés ou non, émanant des établissements d'enseignement et de recherche français ou étrangers, des laboratoires publics ou privés.

\section{(ㅇ)(1) $\$$}

Distributed under a Creative Commons Attribution - NonCommercial - NoDerivatives $\mid 4.0$ 
1 Eggshell matrix proteins OC-116, OC-17 and OCX36 in hen's sperm storage tubules

2 Riou Cindy a,b, Cordeiro Luiz ${ }^{\text {a,c }}$, Gérard Nadine a, ${ }^{\text {a }}$

3 a INRA, UMR INRA85, UMR CNRS 7247, Université de Tours, IFCE, Physiologie de la

4 Reproduction et des Comportements, Interactions Cellulaires et Fertilité, 37380 Nouzilly, 5 France

$6 \quad$ b ALLICE, Station de Phénotypage, Lieu-Dit Le Perroi, 37380 Nouzilly, France

$7 \quad{ }^{\mathrm{c}}$ Federal University of Semi Arid Region, Mossoro, 59625-900, Rio Grande do Norte, Brazil

8 *Corresponding author : E-mail address : nadine.gerard@inra.fr

9 


\section{ABSTRACT}

While uterine epithelium secretes eggshell matrix proteins to regulate eggshell structural organization, uterovaginal junction (UVJ) epithelium supports sperm storage in tubules (SST). Here, we examined the presence of OCX36, OC-116 and OC-17 eggshell matrix proteins in SSTs. Two experimental lines of hens displaying either a long ( $\mathrm{F}+$ line) or a short (F- line) potential to store sperm were used, before and 24 hours after insemination. Using immunohistochemistry and western blot, we analyzed the presence of OC-116, OC-17 and OCX36 proteins in the SSTs. Using lectin and calcium staining, we examined the presence in SSTs of Gal/GalNAc (Galactose/N-acetylgalactosamine) and Glc/GlcNAc (Glucose/Nacetylglucosamine) glycans, as well as calcium ions. Our results indicate that in both $\mathrm{F}+$ and F- hens, the eggshell matrix proteins OC-116 and OCX36 were identified in SST cells and lumen, in contact with spermatozoa. The OC-17 protein was found associated with calcium in $\mathrm{F}+$ and F- hens, only in the SST lumen 24h after insemination. Glycans Gal/GalNAc and Glc/GlcNAc were found to be more abundant in the apical cytoplasmic area of the SST cells of $\mathrm{F}+$ hens than in that of $\mathrm{F}$ - hens after insemination. This is the first report demonstrating the presence in SSTs of the OC-116, OC-17 and OCX36 eggshell matrix proteins, and their concomitant presence with Gal/GalNAc and Glc/GlcNAc glycans, as well as with calcium. Our results suggest that the OC-116, OC-17 and OCX36 eggshell matrix proteins may be involved in sperm storage.

Key words: sperm storage tubule, eggshell matrix protein, glycoconjugates, fowl hen 


\section{Introduction}

The avian oviduct is the site of fertilization of the ovulated oocytes as well as that of egg formation. In hens subjected to copulation or insemination, fertilization occurs in the infundibulum within approximatively 15 minutes after ovulation (Wishart and Staines, 1999). The deposition of albumen, shell membranes, shell and shell cuticle takes place in the magnum, the isthmus, and the uterus, respectively (Richardson, 1935; Sauveur and de Reviers, 1988). All the compounds required are produced within the hen oviduct by highly specialized glands (Richardson, 1935; Hodges, 1974). The prolonged sperm storage takes place in two anatomical regions, the uterovaginal junction (UVJ) and the infundibulum. The UVJ is considered as the main site of sperm storage at least in poultry species (Fujii, 1963; Gilbert et al., 1968; Tingari and Lake, 1973). In both sites, the storage is located in highly specific structures called sperm storage tubules (SST) (Bobr et al., 1964; Hodges, 1974).

The SST epithelium is structured in two distinct regions that are connected to each other. The upper portion which opens into the uterovaginal lumen composed of ciliated cells, and the 'blind portion' exclusively made-up of non-ciliated cells (Van Krey et al., 1967) (Burke et al., 1972; Tingari and Lake, 1973; Bakst and Bauchan, 2015; Waqas et al., 2016). Nonciliated SST cells are the functional portion dedicated to sperm storage in the SST epithelium. These secretory cells were reported to release apocrinal secretions and exosomes (Bakst and Bauchan, 2015; Waqas et al., 2016). They were also reported to contain glycogen, lipids, phospholipid, acid phosphatase (Gilbert et al., 1968; Huang et al., 2016), calcium (Holm et al., 2000) and carbonic anhydrase (Holm et al., 1996). Some of these products, like calcium or carbonic anhydrase, were assumed to impact sperm survival (Fujihara and Koga, 1984; Holm and Ridderstrale, 1998; Holm and Wishart, 1998; Holm et al., 2000). The SST lumen is filled with fluid that also contains several essential factors such as acid phosphatase, lipids (Gilbert et al., 1968) and glycans (Bakst and Bauchan, 2016). Glycans were shown to play a major 
role in the interaction between sperms and oviductal epithelial cells in various species including mammals (DeMott et al., 1995; Lefebvre et al., 1997; Green et al., 2001; Wagner et al., 2002; Kadirvel et al., 2012), birds (Bakst and Bauchan, 2016), and insects (Wong et al., 2008). It was suggested recently that galactose (Gal) and N-acetylgalactosamine (GalNAc) moieties from SST apocrinal blebs might mediate communications between resident sperm and SST cells in the hen's oviduct (Bakst and Bauchan, 2016).

Uterine tissue, located in proximity to the UVJ is an epithelium composed of ciliated and non-ciliated cells which invaginate to form dense array tubular glands (Breen and De Bruyn, 1969). Uterine cells of the surface epithelium and tubular glands display an intense and dynamic secretory activity, leading to the production of uterine fluid which contains all the mineral and organic precursors required for shell formation (Gautron et al., 1997). For example, the uterine fluid is hypersaturated in calcium and bicarbonate ions (Nys et al., 1991), generated by carbonic anhydrase to produce the $\mathrm{CaC} 03$ mineral components of eggshells. The organic phase of the uterine fluid is composed of proteins, glycoproteins and proteoglycans associated with minerals during the course of shell formation (Gautron et al., 1997; Marie et al., 2015). Several proteins constitutive of the matrix proteins involved in the processes of shell mineralization are specifically secreted by uterine cells. Such proteins known as OC-17, OCX36 and OC-116 are the main actors of shell mineralization (Hincke et al., 1995; Hincke et al., 1999; Mann and Siedler, 1999; Fernandez et al., 2001; Reyes-Grajeda et al., 2004; Gautron et al., 2007). These eggshell matrix proteins are involved in calcium aggregation (Gautron et al., 1997) and calcium precipitation (Gautron et al., 1997; Dominguez-Vera et al., 2000) within the uterine fluid. OC-17 is a C-type, lectin-like phosphoprotein of $17 \mathrm{kDa}$ present in glycosylated $(23 \mathrm{kDa})$ and non-glycosylated forms in the shell matrix (Hincke et al., 1995). It has been related to eggshell strength (Sun et al., 2013). OCX36 is an eggshell protein belonging to the superfamily of lipopolysaccharide-binding proteins/bactericidal 
80

81

permeability-increasing proteins and Plunc proteins (Gautron et al., 2007). Both proteins play an antimicrobial role which was clearly established recently (Gautron et al., 2007; WellmanLabadie et al., 2008). OC-116 is a protein core of 120-200 kDa eggshell dermatan sulfate proteoglycan termed ovoglycan which is present in the compact calcified eggshell (Hincke et al., 1999).

In hens, the sperm filling/emptying processes in SST is dependent on egg passage through the oviduct (Brillard et al., 1987). Moreover, it was suggested that some regulators of eggshell quality may interfere with in vivo sperm storage (Bilgili et al., 1984). In the present study, we hypothesized that sperm storage in the uterovaginal SST is related to the process of shell mineralization. We used two lines of hens previously selected for their high or low capacity to preserve sperm and to produce hatched chicks (Brillard et al., 1998). After determining the duration of the fertile period in each line, we compared the expression of OCX36, OC-17, OC-116 secreted proteins and sugar residues in their uterine fluid, SST cells and lumen, and studied the interaction between SST secretory products and sperm.

\section{Materials and methods}

\subsection{Birds}

Sexually mature hens issued from two lines previously selected for their ability to produce high $(\mathrm{F}+)$ or low $(\mathrm{F}-)$ numbers of hatched chicks, and to preserve sperm in their SST for longer $(\mathrm{F}+)$ or shorter $(\mathrm{F}-)$ periods, were used in this study. These two lines were thus different in the duration of their fertile period, the F- line expressing a shorter time potential to lay fertile eggs than the $\mathrm{F}+$ line (Beaumont et al., 1992). Breeding procedures and handling protocols were carried out according to the European Community Council Directives regarding the practice for care and use of animals and of the recommendations of the French Ministry of Agriculture on Animal Experimentation under the supervision of an authorized 
scientist (Authorization \# 37035). Farm facilities (Institut National de la Recherche Agronomique, UE-PEAT, 1295) are recognized as officially authorized to rear and euthanize birds (B27-175-1 dating back to August 28th, 2012). At 43 wks of age, hens were placed in individual cages equipped with automatic devices to record the time of oviposition. They were kept under a 16L: 8D photoperiod, and fed a layer mash ad libitum.

\subsection{Fertility Rates and Duration of Fertile Period}

The duration of the fertile period within each line was expressed using two definitions: effective duration (De), the number of days after artificial insemination (AI) during which a hen lays $100 \%$ fertile eggs; and maximum duration (Dm), the number of days after AI until the hen lays its last fertile egg. At 45 wks of age, $F+(n=28)$ and $F-(n=27)$ hens were inseminated on two consecutive days with $200 \times 10^{6}$ sperm from mixed ejaculates collected from 6 broiler breeder males on both days. The eggs were identified individually and recorded daily from Day 2 to Day 22 following the second AI. They were stored for a maximum of 7 days prior to incubation. The percentage of fertile eggs was determined by candling on Day 7 of incubation. Eggs primarily classified as infertile were broken up for macroscopic examination of the germinal disc to determine the presence of dead blastodiscs, if any. Comparisons for De, Dm, and fertility, laying and embryo mortality rates between the two lines were computed using a Mann-Whitney test $(\mathrm{P}<0.05)$.

\subsection{Collection of uterine fluid and sperm incubation}

The collection of uterine fluid (UF) was planned individually 10 hours after a naturally achieved oviposition, from $\mathrm{F}+(\mathrm{n}=4)$ and $\mathrm{F}-(\mathrm{n}=4)$ hens that display high and similar laying rates (0.8-1 egg/day). The presence of a forming egg in utero was confirmed and its expulsion from the uterus was carried out by intravenous injection of $50 \mu \mathrm{g}$ of prostaglandin F2 $\alpha$. During 
egg expulsion, the UF was collected by abdominal massage into a plastic tube placed at the opening of the everted vagina (Gautron et al., 1997).

Spermatozoa from 6 broiler breeder males were rinsed 3 times in BPSE diluent (10 min, 600g). They were incubated at $41{ }^{\circ} \mathrm{C}$ during 1 hour in UF collected from F- or F+ hens at a final concentration of $1 \times 10^{6}$ sperm $/ \mathrm{mL}$. Spermatozoa were rinsed in PBS and fixed in $4 \%$ saline buffered (PBS) formalin before immunohistochemistry procedure.

\subsection{Tissue Collection}

Tissue samples of the uterus, vagina and uterovaginal junction (UVJ) were collected for histochemistry between 8-10 hours after oviposition. Hens that display high and similar laying rates (0.8-1 egg/day) were euthanized by cervical dislocation, either before AI ( $\mathrm{n}=3$ for each line) or 24 hours after AI ( $\mathrm{n}=3$ for each line). The whole oviduct from uterus to vagina was excised as one segment. Connective tissue was removed to expose the UVJ. Samples of uterus, vagina and UVJ mucosa containing SST were collected from each hen and processed.

\subsection{Western blotting}

The protein concentration was determined in each UF sample individually, by the Pierce ${ }^{\circledR}$ BiCinchoninic Acid protein assay kit (Life Technologies SAS, Saint Aubin, France) using bovine serum albumin as the protein standard and according to the manufacturer's instructions. Ten $\mu \mathrm{g}$ of UF proteins were added to $5 \mathrm{x}$ Laemmli buffer $(5 \mathrm{v}: 1 \mathrm{v})$, boiled at $95^{\circ} \mathrm{C}$ for 5 min, then loaded and separated on a 10\% SDS-PAGE, before being transferred to nitrocellulose membranes. The membranes were washed with TBS $(10 \mathrm{mM}$ Tris, $150 \mathrm{mM}$ $\mathrm{NaCl}, \mathrm{pH}$ 7.4) containing $0.1 \%$ (v/v) Tween-20 (TBS-T), incubated for 1 hour in the blocking solution $(5 \%(\mathrm{w} / \mathrm{v})$ non-fat dry milk in TBS-T), and overnight in the blocking solution containing anti-OC-17, anti-OC-116, or anti-OCX36 (1:1000 each). All antibodies were polyclonal produced in the rabbit and kindly provided by J. Gautron (Unite de Recherches 
Avicoles, INRA, Nouzilly, France). The membranes were then sequentially washed with TBS-T, incubated for 1 hour in the blocking solution, then for 1 hour with peroxidaseconjugated secondary antibody, i.e. goat anti-rabbit IgG (A6154, Sigma-Aldrich, Saint Quentin Fallavier, France) diluted 1:5000 in the blocking solution, and finally washed with TBS-T. The peroxydase activity was detected with the ECL select ${ }^{\mathrm{TM}}$ Western Blotting Detection Reagent (GE Healthcare, Velizy-Villacoublay, France), the signal was captured by mean of an ImageMaster VDS-CL bio imaging system (Amersham Biosciences/GE Healthcare) and quantified using Image Quant software. Signal was then normalized on the total loaded protein quantity (Ponceau red).

\section{6. $\quad$ Histochemistry Preparation for Immuno and Lectin Detection}

Following 24 hours fixation in 4\% saline buffered (PBS) formalin, tissue samples (uterus, vagina and UVJ) were transferred to two successive bathes of $70 \%$ ethanol $(2 \times 30 \mathrm{~min})$, and then moved to an automated system tissue processor (Leica TP1020 Semi-enclosed Benchtop Tissue Processor). The samples were then embedded in paraffin (Leica EG1150 Modular Tissue Embedding Center, Leica Microsystems Richmond, Inc., Richmond, IL). Four to six 7$\mu \mathrm{m}$ thick sections were collected in sequence onto slides treated with albumin, air-dried overnight, stored at room temperature (RT) for 12 hours and then incubated overnight at $60^{\circ} \mathrm{C}$. The staining procedures consisted in deparaffinization for $5 \mathrm{~min}$ in toluene, followed by progressive rehydration $(100 \%, 95 \%, 80 \%$ and $70 \%$ ethanol bathes, 2 min each) and removal of ethanol excess by water bathes.

\subsection{Immunohistochemistry}

After dehydration, the slides were treated with $1 \%$ citrate based unmasking solution H3300 (Vector Laboratories, Burlingame, CA) diluted as recommended by the manufacturer. The slides were rinsed once in TBS for 5 min and then placed in a bath with normal horse serum 
blocking solution (Vector) for $20 \mathrm{~min}$. The slides were incubated overnight at $4{ }^{\circ} \mathrm{C}$ with the primary antibodies, anti-OC-17 (1:500), anti-OC-116 (1:500) or anti-OCX36 (1:500) diluted in TBS with 5\% non-fat dry milk. The slides were then washed 3 times in TBS (5 min), and incubated for 30 min with the secondary antibody ImmPRESS ${ }^{\mathrm{TM}}$ HRP Anti-Rabbit/Mouse $\operatorname{IgG}$ (Vector) and rinsed in TBS (5 min), incubated with peroxidase ImmPACT NovaRED (Vector) and finally rinsed in distilled water $(5 \mathrm{~min})$. Sections were counterstained with Papanicolaou stain (Sigma). Coverslips were applied with aqueous mounting medium after dehydration through graded alcohol bath $(70 \%, 80 \% 95 \%, 100 \% ; 20 \mathrm{sec}$ each) and incubation of the sections in toluene (1 min). The sections were examined using an Axioplan Carl Zeiss microscope. Images were acquired using a digital monochrome camera (Spot-Flex, Diagnostic Instruments) coupled with the SPOT 5.2 imaging software. The same procedure was used for negative control of the slides with an exception for the first antibody. Negative controls for immunohistochemistry demonstrated the absence of unspecific signal making the procedure reliable.

\section{8. $\quad$ Von Kossa staining}

Calcium deposits in the UVJ tissue were detected using the Von Kossa staining method. Briefly, deparaffinized and rehydrated sections were incubated with $2 \%$ silver nitrate solution. The slides were exposed to UV for 20 min until a light brown signal appeared, then rinsed in distilled water before removal of unreacted silver with a $5 \%$ sodium thiosulfate solution ( 5 min). The sections were rinsed several times in water, counterstained with Papanicolaou staining, gradually dehydrated (in $70 \%, 80 \%, 90 \%$ and $100 \%$ ethanol, for 2 min each) and cleared in toluene $(5 \mathrm{~min})$. The slides were permanently covered with Depex ${ }^{\circledR}$ aqueous mounting medium. Calcium deposits were observed as a light to dark brown signal.

\subsection{Lectin Histochemistry}


Lectins (Vector Laboratories, Burlingame, CA) used in this study are reported in Table 1.

201

202

For each set of slides processed, two negative controls were prepared: one slide was incubated without lectin to detect auto-fluorescing cells, and another slide was incubated in the presence of lectin and of its inhibiting sugar for at least $40 \mathrm{~min}$. All slides were incubated for $10 \mathrm{~min}$ in TBS prior to tissue labeling with a single lectin at its optimized concentration for $60 \mathrm{~min}$ (Table 1). The slides were transferred 3 times for $10 \mathrm{~min}$ in TBS, and then washed for $3 \mathrm{~min}$ in deionized water. This procedure was repeated for dual lectin labeling. Coverslips were applied with Fluoromount-G® (Southern Biotech, USA) mounting medium. The slides were protected from light during the process of fluorescence conjugated-lectin labelling. Then, the slides were dried in the dark at room temperature for 24 hours and stored at $4 \circ \mathrm{C}$ until analysis. Imaging was completed within one week after labeling. The sections were examined using a Zeiss LSM 700 confocal microscope equipped with the Zen 2012 64-bit image acquisition and processing software. The negative control procedure for lectin histochemistry demonstrated the absence of unspecific signal, making the procedure reliable for sugar detection.

\section{Results}

\subsection{Fertility characteristics of $F+$ and $F$ - hens}

As shown in Figure 1 and Table 2, a highly significant difference was recorded in most fertility parameters between the two selected lines, with up to a $27.8 \%$ increase in egg fertility rate between $\mathrm{F}+$ hens and $\mathrm{F}-$ hens $(\mathrm{P}<0.001)$. Moreover, the fertile period of $\mathrm{F}+$ hens exceeded that of F- hens by 1.9 and 6.0 days for De and Dm, respectively $(\mathrm{P}<0.05$ and $\mathrm{P}<$ 0.001). Accordingly, the mean percentage of fertile eggs was constantly higher in $\mathrm{F}+$ than in F- eggs over the three weeks after insemination. The mean differences in fertile eggs were 19.7, 53.2 and $13.9 \%$ during weeks 1,2 and 3, respectively $(\mathrm{P}<0.01, \mathrm{P}<0.001$ and $\mathrm{P}<$ 
0.001). Moreover, the laying rates were significantly higher in $\mathrm{F}+$ hens than in $\mathrm{F}$ - hens $(\mathrm{P}<$ 0.01) over the experimental period. No significant difference between the two lines was recorded in the percentage of embryo survival, irrespective of the week following insemination.

\section{2. $O C-116, O C-17$ and OCX36 in uterine fluid (UF)}

OC-116, OC-17 and OCX36 were detected by Western blot in UF at 116kDa, 36kDa and $17 \mathrm{kDa}$, respectively (Figure 2A). As shown in Figure 2B, the signals were stronger for $\mathrm{F}+$ hens than for F- hens, even though the difference is not significant. Nevertheless, the immuno-detection signals of all the three proteins tended to increase after AI in F- hens, whereas they tended to decrease in $\mathrm{F}+$ hens.

\subsection{OC-116, OC-17 and OCX36 immunohistochemistry in vagina and uterus}

We observed that the epithelium of the vagina and uterus showed different affinities for OC-116, OC-17 and OCX36 antibodies. None of the 3 proteins were detected in the vagina epithelium (Figures 3A-C). OC-116 was localized in the uterine surface epithelium (Figure 3E) while OC-17 was localized exclusively in the uterine glandular epithelium (Figure 3F). OCX36 was detected neither in the uterine epithelium, nor in the uterine glandular epithelium (Figure 3G). Negative controls for immunohistochemistry demonstrated the absence of unspecific signal in vagina (Figure 3D) and uterus (Figure 3H).

\section{4. $O C-116, O C-17$ and OCX36 immunohistochemistry in UVJ}

\subsubsection{OC-116 protein}

OC-116 was localized in UVJ surface epithelial cells and in SST cells cytoplasm (Figures 4A-D). Moreover, in both $\mathrm{F}+$ and $\mathrm{F}-$ hens, the signal appeared luminal even before AI (Figures 4A, 4C, 4C inset) or after AI (Figures 4B, 4B inset i, 4D, 4D insets iii and v). Interestingly after AI, the luminal staining was in contact with spermatozoa in F- hens (Figure 
4B inset ii) and surrounded spermatozoa in F+ hens (Figure 4D insets v and vi). Moreover, we observed a granular secretory product with an intense staining for OC-116 projecting outside SST (Figure 4D insets iii and iv). OC-116 displayed a crown-shaped signal around spherical structures localized inside SST (Figure 4D inset vii).

\subsection{2. $O C-17$ protein}

OC-17 has never been reported in UVJ tissue, neither in the epithelium nor in SST cells, whatever the genetic line, before or after AI (Figure 5). Twenty-four hours after AI, some signal for OC-17 was localized in the lumen of SST in both F- (Figure 5B inset), and F+ (Figure 5G inset i) hens. OC-17 reactivity co-localized with Von Kossa calcium staining (Figure 5G inset ii). This co-staining was observed in SST filled with spermatozoa (Figure 5D insets $\mathrm{i}$ and ii). Negative controls for immunohistochemistry demonstrated the absence of unspecific signal in UVJ from F- (Figure 5C) and $\mathrm{F}+($ Figure $5 \mathrm{H})$ hens after AI, as well as in sperm incubated with UF collected from F- (Figure 5D) and F+ (Figure 5I) hens. No reactivity was detected in sperm incubated with UF collected from F- (Figure 5E) and F+ (Figure 5J) hens.

\subsubsection{OCX36 protein}

In UVJ, no signal for OCX36 was detected in surface epithelial cells, but was specifically observed in SST cells from both F+ and F- hens, either without AI or 24h after AI (Figures 6A-D). Without AI, the signal was heterogeneous, and located in the cytoplasm of SST cells in both F- (Figure 6A) and F+ (Figure 6C) hens. Moreover, a granular signal was also observed projecting in the lumen of SST from F- (Figure 6A insets $\mathrm{i}$ and ii) and $\mathrm{F}+$ hens (Figure 6C inset). After AI, the localization of OCX36 was mainly luminal in F- hens, with only a small amount observed in the cytoplasm of few cells (Figure 6B). Some spermatozoa appeared enclosed in a substance positive for OCX36 staining (Figure 6B inset). In contrast, 
273 in F+ hens after AI, the OCX36 signal was very strong within the cytoplasm all along the SST 274 (Figure 6D).

3.5. Lectin histochemistry

3.5.1. Lactosamine (Galß1->4GlcNAc), Terminal N-acetylgalactosamine (GalNAc) and $N$-acetylglucosamine (GlcNAc) residues in the vagina and uterus

As shown in Figure 7, we observed that in vaginal and uterine tissues, ECL and WGA bound with high affinity the Gal $\beta 1->4$ GlcNAc and the GlcNAc residues, respectively. Moreover, SBA bound with low affinity the GalNAc residues from both tissues. In vagina, ECL staining was strong in the cytoplasm of some epithelial cells, as well as in loose connective tissue (Figure 7A). Moreover, SBA lectin bound to lymphocytes of loose connective tissue (Figure 7B), and WGA bound with strong affinity to the cytoplasmic part of some epithelial cells (Figure 7C). Negative controls for lectin histochemistry demonstrated the absence of unspecific signal in vagina (Figure 7D). In uterus, ECL staining was demonstrated in the cytoplasmic and the apical part of surface epithelial cells (Figure 7E), and of tubular gland cells (Figure 7E inset, arrowhead). SBA lectin bound to lymphocytes of loose connective tissue, as previously observed in the vagina (Figure 7F). WGA strongly bound to the apical part of uterine surface epithelial cells as well as that of tubular gland cells (Figure 7G inset, arrowhead), and with less intensity to their cytoplasmic compartment (Figure 7G). Negative controls for lectin histochemistry demonstrated the absence of unspecific signal in uterus (Figure $7 \mathrm{H})$.

\subsection{2. $N$-acetylglucosamine (GlcNAc) residues in UVJ}

In UVJ, WGA staining differed between $\mathrm{F}+$ and $\mathrm{F}$ - hens both in non-inseminated and inseminated females (Figure 8). In non-inseminated F- hens WGA staining was apparent in the cytoplasm of some surface epithelial cells and SST cells, although irregular, less 
297

298

299

300

301

302

303

304

305

306

307

308

309

310

311

312

313

314

315

316

317

318

319

320

homogenous and stronger in the former (Figure 8A). In non-inseminated $\mathrm{F}+$ hens WGA staining was apparent in the apical part of surface epithelial cells and SST cells, although more homogenous and stronger in the latter (Figure $8 \mathrm{C}$ ). Of note is the differential WGA staining of the apical region of UVJ cells from F+ and F- hens. After AI, WGA displayed specific staining patterns. In F- UVJ tissue, it appeared strongly bound to the apical and supranuclear part of surface epithelial cells and SST cells (Figure 8B), whereas in F+ UVJ tissue, it strongly highlighted the cytoplasmic part of some surface epithelial cells, as well as the apical part of SST cells (Figure 8 inset i). This staining was associated with a strong staining of the SST lumen too (Figure 8D inset ii). Of note was the absence of WGA staining within the F+ SST cells concomitant with an intense staining of SST cell apex (Figure 8D).

\subsubsection{Lactosamine (Gal $\beta 1->4 G l c N A c$ ) residues in the UVJ}

In UVJ, ECL binding differed between $\mathrm{F}+$ and $\mathrm{F}$ - hens, both in non-inseminated and inseminated females (Figure 9). In non-inseminated F-, it appeared bound irregularly and strongly to cytoplasmic and apical parts of some surface epithelial cells and SST cells (Figure $9 \mathrm{~A}$ inset $\mathrm{i}$ and ii). In non-inseminated $\mathrm{F}+$ hens, it appeared bound regularly to the apical part of epithelial and SST cells (Figure 9C). Moreover, ECL staining was visualized in loose connective tissue from F- UVJ tissue, but not in that from F+. After AI, ECL displayed specific staining patterns. In F- UVJ tissue, it homogeneously bound to the top of cilia from the surface epithelium (Figure 9B, arrowhead), as well as to the apical and the cytoplasmic parts of SST cells (Figure 9B inset iii). Moreover, some SST cells showed an intense ECL staining. We also observed that the SST lumen displayed ECL staining (Figure 9B inset iv). Furthermore, the F- UVJ loose and dense connective tissue was strongly stained by ECL lectin. In F+ hens after AI, ECL staining was observed irregular and strong in cytoplasmic and apical parts of some surface epithelial cells (Figure 9D inset vi) and some SST cells 
321 (Figures 9D encircled, 9D inset v). Furthermore, it is of note that in both F+ and F- UVJ 322 collected after AI, some SST cells were strongly stained by ECL lectin (Figures 9 B-D).

\subsubsection{Terminal N-acetylgalactosamine (GalNAc) residues in the UVJ}

324

The staining density of SBA lectins appeared similar in the in UVJ tissues of F+ and Fhens (Figure 10). In non-inseminated hens, SBA lectin was bound the cytoplasmic and apical parts of SST cells (Figures 10 A-D). After insemination, the SBA staining was localized to the top of cilia from epithelium as a thick layer (Figures 10B, 10B inset i and Figure 10D inset, arrowheads). Moreover, the SBA staining displayed a stronger signal at the apical part of SST cells (Figures 10B-D) and lumen (Figure 10B inset ii and Figure 10E) than in surface epithelial cells. Interestingly, the intense luminal staining in $\mathrm{F}+$ hens observed in Figure 10D appears to surround the underlying spermatozoa shown in Figure 10E. Moreover, some SST cells are intensively stained with SBA lectin.

\section{Discussion}

The present work examined the expression of OCX36, OC-17 and OC-116, three glycoproteins known to participate to the eggshell calcification, within SSTs in which sperm is stored for quite a long period of time. Actually, we hypothesized that sperm storage within SSTs and the eggshell mineralization process by the uterus are related.

Using two lines of hens ( $\mathrm{F}+$ and $\mathrm{F}-$ ), we showed that the genetic divergence on the duration of fertility remains as originally described (Brillard et al., 1998). The F- hens are characterized by a reduced fertility, a reduced laying rates, as well as shorter efficient and maximal durations of fertility when compared to the F+ line. Fertilization rates after the first, the second and the third week post-insemination were also significantly reduced in F- hens, in 
comparison to $\mathrm{F}+$ hens, as previously described (Brillard et al., 1998). Therefore these two lines are a suitable model to study the regulation of sperm storage duration in hens, and more generally in avian species.

We showed for the first time in the present study that SST epithelial cells, but not UVJ surface epithelial cells, express simultaneously eggshell matrix proteins OC-116 and OCX36 concomitantly with the presence of sugar residues Gal/GalNAc and Glc/GlcNac. In addition, this work is the first that show the presence of OC-17 in SST lumen. Nevertheless, we did not observed any OC-17 signal within SST cells during our immunolocalization experiment. Thus, OC-17 may either be secreted as soon as synthesized by SST cells, or less probably, it may originate from uterine tubular glands and then accumulates in SSTs. Of note that OC-17 originating from the uterine fluid was never found attached to sperm after in vitro incubation. This indicates that OC-17 in SST lumen was not absorbed onto sperm membrane. In the present study, the presence of OC-17, OC-116 and OCX36 was associated with calcium deposits. Considering the role of eggshell proteins on calcium aggregation (Gautron et al., 1997) and eggshell quality (Sun et al., 2013), the present study confirms previous observations showing that eggshell quality regulators interfere with sperm storage (Bilgili et al., 1984). This leads us to hypothesize that eggshell matrix proteins may display important feature for sperm storage.

OC-116 is a protein core of a proteoglycan named ovoglycan, composed of dermatan sulfate glycosaminoglycan chains that contain disaccharide units of both $\mathrm{N}$-acetylglucosamine and iduronic acid. It was first identified in eggshell (Carrino et al., 1996; Carrino et al., 1997; Hincke et al., 1999; Fernandez et al., 2001). The precise role of this macromolecule is not clearly known, considering the complexity of the proteoglycan part containing dermatan sulfate (length, localization of L-iduronic acid, sulfation etc.), associated to the core protein specificity. All in all, dermatan sulfate macromolecules are known to have binding 
369

370

371

372

capabilities for various extracellular matrix proteins, growth factors (TGFb), protease inhibitors, cytokines, chemokines, and pathogen virulence factors (Trowbridge and Gallo, 2002). In the context of mineralization, it has been proposed that the negative charges of acidic ovoglycan confer the capacity to attract divalent ions like calcium (Hincke et al., 1999). This is supported by recent works demonstrating that glycosaminoglycans can entrap calcium as nanoparticles (20-60 nm) during crystallization process in vitro (Chen et al., 2010; Chen et al., 2012).

In mammals, OC-116 ortholog MEPE encodes the matrix extracellular phosphoglycoprotein (MEPE), which has been shown to be involved in bone mineralization. OC-116 and its mammalian orthologue MEPE are part of the Small Integrin-Binding Ligand, N-linked Glycoprotein (SIBLINGS) family containing non collagenous proteins that are mainly expressed in mineralized tissues, bone, and dentin (Fisher et al., 2004; Bellahcene et al., 2008; Bardet et al., 2010). One of the most significant differences between OC-116 and other SIBLINGs (including mammalian MEPE) is its original identification as a dermatan sulfate proteoglycan. As such, OC-116 was thought to influence calcitic mineralization, in part via interaction with sulfate anion (Rose and Hincke, 2009). Nevertheless, OC-116 is also a major phosphoprotein of the eggshell matrix (Mann et al., 2007), and was recently identified in young chick cortical bone, laying hen medullary bone and growth plate hypertrophic chondrocytes suggesting a possible role in calcium phosphate mineralization. Different posttranslational modifications in the OC-116 protein are likely important in determining the nature and influence of OC-116 interaction with calcium carbonate in eggshell or calcium phosphate in bone. Although there is no evidence yet for the presence of calcium carbonate or calcium phosphate in SST lumen, the presence of OC-116 suggests at least the modulation of SST luminal calcium deposits. Distribution of the two forms of OC-116 (proteoglycan and phosphoprotein) within SSTs, i.e. phosphorylated, N-glycosylated or glycanated, need to be 
further investigated. Our study confirms the presence of several intracellular and apical sugar moieties, suggesting that OC-116 could be at least glycosylated in SSTs.

Considering its role in calcium modulation, we suggest that OC-116 acts as a calcium chelator regulating OC-116-bathing-sperm motility as well as sperm viability in SSTs. This could be related to previous data demonstrating that the addition of calcium in sperm diluents improves sperm viability (Fujihara and Koga, 1984; Wishart and Ashizawa, 1987; Wishart and Wilson, 1999). Moreover, Froman (2003) proposed a model of sperm behavior to enter and survive in SSTs, based on the role of calcium on sperm motility (Froman, 2003).

Ovocleidin-17 (OC-17) is an abundant component of the soluble fraction of the uterine fluid and it is also glycosylated (Mann, 1999). It is one of the major candidates to regulate mineral deposition. Based on its amino acid sequence, OC-17 contains two phosphorylated sites, and a C-type lectin-like domain (Mann, 1999) like other avian homologous eggshell matrices (Mann and Siedler, 2004; Lakshminarayanan et al., 2005; Mann and Siedler, 2006). Of note, C-type lectin-like domain containing proteins are associated with the mineral phase of calcium carbonate.

This is the first study reporting the co-localization of OC-17 and calcium positive substance, in relation to sperm storage in SSTs. This co-localization was observed only after insemination, and only in sperm-filled SSTs, suggesting that sperm may regulate the release of calcium from the SST epithelium. Alternatively, this co-localization of OC-17 and calcium suggests a modulation in the SST luminal environment, since OC-17 is known to participate in the crystallization of amorphous calcium carbonate (Reyes-Grajeda et al., 2004). The presence of the OC-17 protein and calcium ions inside SST may illustrate the dynamic activity of cells that may lead to the modulation of the environment to permit sperm retention or release. This is consistent with the fact that eggshell matrix proteins are secreted in variable 
418 quantities by the uterine surface epithelium or tubular glands during shell mineralization 419 (Marie et al., 2015).

420 One potential role of OC-17 and OCX36 proteins could be to maintain a bacteria free 421 environment in the SST lumen. Indeed, OCX36 belongs to the superfamily of 422 lipopolysaccharide-binding proteins/bactericidal permeability-increasing proteins and Plunc 423 proteins which displays antimicrobial activity (Gautron et al., 2007). The OC-17 protein is a 424 C-type lectin like phosphoprotein that also exhibits antimicrobial properties (Wellman425 Labadie et al., 2008).

Interestingly, we recorded differences between the two lines of hens regarding staining 427 intensity and localization of both the Gal/GalNAc and Glc/GlcNAc moieties, 24 hours after 428 insemination. Our observations suggest a higher secretory activity in F+ SST cells after 429 insemination than in F- SST cells. Thus, our results support the importance of 430 glycoconjugates, probably originating from eggshell matrix proteins, on the duration of sperm 431 storage, as proposed recently by Bakst et al. (2016) (Bakst and Bauchan, 2016). Associated 432 with the fact that the localization of Gal/GalNAc and Glc/GlcNAc moieties was different in $433 \mathrm{~F}+$ and $\mathrm{F}$ - hens before AI, our results suggest a discrepant sensitivity to insemination of SST 434 cells in the two lines.

435 Glycan-mediated interactions are known to be involved in the attachment of sperm to the oviduct epithelium in mammalian sperm reservoir (Suarez, 2001). N-acetylglucosamine 437 moieties, as well as galactose moieties, are involved in sperm adherence to epithelial cells 438 (Suarez, 2016). In hen's oviduct, galactose and N-acetylgalactosamine moieties have been 439 recently proposed to mediate sperm attachment to SST epithelial cells in turkey (Bakst and 440 Bauchan, 2016). Galactose and N-acetylgalactosamine moieties can be part of 441 galactosaminoglycans that are anionic polysaccharides covalently attached to core proteins to 442 form proteoglycans. These polysaccharides have been associated to eggshell mineralization in 
hen's oviduct (Nakano et al., 2002). Moreover, dermatan sulfate proteoglycan OC-116 is a galactosaminoglycan composed of $\mathrm{N}$-acetylgalactosamine and $\mathrm{N}$-acetylglucosamine residues that combine to form the major motif that is present on the molecule, LacDiNAc (GalNAc $\beta 1$ 4GlcNAc). Interestingly, OC-116 contains several fucosylated forms of LacDiNAc motif (Nimtz et al., 2004). However, fucose residues are known to be key components of sperm binding to mammalian oviduct (Suarez, 2008). Furthermore, it has been reported that OC-17 contains $\mathrm{N}$-acetylgalactosamine, but not $\mathrm{N}$-acetylglucosamine moieties (Hincke et al., 1995). Therefore, a better understanding of the role of the eggshell matrix proteins (OC-116 and OC17) and their $\mathrm{N}$-acetylgalactosamine and $\mathrm{N}$-acetylglucosamine moieties is needed in the context of sperm adherence on SST epithelial cells.

In conclusion, this is the first study reporting the presence of OC-116, OCX36 and OC-17 eggshell matrix proteins in SSTs, their concomitant expression with Gal/GalNAc and Glc/GlcNAc, as well as with calcium and sperm. Our results suggest that the storage of sperm in the SSTs and the eggshell mineralization process, assumed by OC-116, OCX36 and OC17 , may be related. In our view, the present study also opens up new research prospects. Thus, the study of the presence of eggshell matrix proteins, glycoconjugates and calcium in infundibulum, specifically in SSTs, should receive interest to better understand their role in avian species like in $\mathrm{F}+$ and $\mathrm{F}$ - hen genetic lines. Another matter of interest refers to the main biochemical properties of the eggshell matrix proteins which appear well conserved in most avian species and other sauropsids (snakes, crocodiles, turtles) (Panheleux et al., 1999; Bardet et al., 2010). Considering that these species are also known to maintain sperm survival in their genital tract (Holt, 2011), the study of eggshell matrix proteins expression should receive additional attention to better understand their role(s) at maintaining a local environment favoring the long term storage of sperm in SSTs. 


\section{Acknowledgments}

We thank Murray Bakst and Jean-Pierre Brillard for their helpful discussions during the manuscript writing. We are grateful to the personnel of avian experimental unit (UE-PEAT, INRA, Nouzilly) for the care of birds. We acknowledge the personnel of the PIC platform (PRC, INRA, Nouzilly) and of the laboratory of animal infection expertise (ISP, INRA, Nouzilly) for providing help and technical expertise in microscopy approach.

L. Cordeiro was supported by $\mathrm{CNPq}$, national council of scientific and technological development, Brazil.

\section{References}

Bakst, M.R., Bauchan, G., 2015. Apical blebs on sperm storage tubule epithelial cell microvilli: their release and interaction with resident sperm in the turkey hen oviduct. Theriogenology 83, 1438-1444.

Bakst, M.R., Bauchan, G., 2016. Lectin staining of the uterovaginal junction and spermstorage tubule epithelia in broiler hens. Poult Sci 95, 948-955.

Bardet, C., Vincent, C., Lajarille, M.C., Jaffredo, T., Sire, J.Y., 2010. OC-116, the chicken ortholog of mammalian MEPE found in eggshell, is also expressed in bone cells. Journal of experimental zoology. Part B, Molecular and developmental evolution 314, 653-662.

Bellahcene, A., Castronovo, V., Ogbureke, K.U., Fisher, L.W., Fedarko, N.S., 2008. Small integrin-binding ligand N-linked glycoproteins (SIBLINGs): multifunctional proteins in cancer. Nature reviews. Cancer 8, 212-226.

Bilgili, S.F., Renden, J.A., Krista, L.M., 1984. Relationships among Fertility, Sperm Storage, and Shell Quality. Poultry Science 63, 2292-2295.

Bobr, L.W., Lorenz, F.W., Ogasawara, F.X., 1964. Distribution of Spermatozoa in the Oviduct and Fertility in Domestic Birds. I. Residence Sites of Spermatozoa in Fowl Oviducts. J Reprod Fertil 8, 39-47.

Breen, P.C., De Bruyn, P.P., 1969. The fine structure of the secretory cells of the uterus (shell gland) of the chicken. Journal of morphology 128, 35-65.

Brillard, J.P., Beaumont, C., Scheller, M.F., 1998. Physiological responses of hens divergently selected on the number of chicks obtained from a single insemination. $\mathrm{J}$ Reprod Fertil 114, 111-117.

Brillard, J.P., Galut, O., Nys, Y., 1987. Possible causes of subfertility in hens following insemination near the time of oviposition. Br Poult Sci 28, 307-318.

Burke, W.H., Ogasawara, F.X., Fuqua, C.L., 1972. A study of the ultrastructure of the uterovaginal sperm-storage glands of the hen, Gallus domesticus, in relation to a mechanism for the release of spermatozoa. J Reprod Fertil 29, 29-36.

Carrino, D.A., Dennis, J.E., Wu, T.M., Arias, J.L., Fernandez, M.S., Rodriguez, J.P., Fink, D.J., Heuer, A.H., Caplan, A.I., 1996. The avian eggshell extracellular matrix as a model for biomineralization. Connect Tissue Res 35, 325-329. 
Carrino, D.A., Rodriguez, J.P., Caplan, A.I., 1997. Dermatan sulfate proteoglycans from the mineralized matrix of the avian eggshell. Connect Tissue Res 36, 175-193.

Chen, Z., Zhou, H., Wang, X., Sang, L., Wang, C., Ma, J., Li, X., 2010. Controlled mineralization by extracellular matrix: monodisperse, colloidally stable calcium phosphate-hyaluronan hybrid nanospheres. Chemical communications 46, 1278-1280.

Chen, Z.H., Ren, X.L., Zhou, H.H., Li, X.D., 2012. The role of hyaluronic acid in biomineralization. Front Mater Sci 6, 283-296.

DeMott, R.P., Lefebvre, R., Suarez, S.S., 1995. Carbohydrates mediate the adherence of hamster sperm to oviductal epithelium. Biol Reprod 52, 1395-1403.

Dominguez-Vera, J.M., Gautron, J., Garcia-Ruiz, J.M., Nys, Y., 2000. The effect of avian uterine fluid on the growth behavior of calcite crystals. Poult Sci 79, 901-907.

Fernandez, M.S., Moya, A., Lopez, L., Arias, J.L., 2001. Secretion pattern, ultrastructural localization and function of extracellular matrix molecules involved in eggshell formation. Matrix Biology 19, 793-803.

Fisher, L.W., Jain, A., Tayback, M., Fedarko, N.S., 2004. Small integrin binding ligand Nlinked glycoprotein gene family expression in different cancers. Clinical cancer research : an official journal of the American Association for Cancer Research 10, 8501-8511.

Froman, D., 2003. Deduction of a model for sperm storage in the oviduct of the domestic fowl (Gallus domesticus). Biol Reprod 69, 248-253.

Fujihara, N., Koga, O., 1984. Prevention of the Production of Lipid Peroxide in Rooster Spermatozoa. Animal Reproduction Science 7, 385-390.

Fujii, S., 1963. Histological and Histochemical Studies on the Oviduct of the Domestic Fowl with Special Reference to the Region of Uterovaginal Juncture. Arch Histol Jpn 23, 447459.

Gautron, J., Hincke, M.T., Nys, Y., 1997. Precursor matrix proteins in the uterine fluid change with stages of eggshell formation in hens. Connective Tissue Research 36, 195-210.

Gautron, J., Murayama, E., Vignal, A., Morisson, M., McKee, M.D., Rehault, S., Labas, V., Belghazi, M., Vidal, M.L., Nys, Y., Hincke, M.T., 2007. Cloning of ovocalyxin-36, a novel chicken eggshell protein related to lipopolysaccharide-binding proteins, bactericidal permeability-increasing proteins, and plunc family proteins. The Journal of biological chemistry 282, 5273-5286.

Gilbert, A.B., Reynolds, M.E., Lorenz, F.W., 1968. Distribution of spermatozoa in the oviduct and fertility in domestic birds. V. Histochemistry of the uterovaginal sperm-host glands of the domestic hen. J Reprod Fertil 16, 433-444.

Green, C.E., Bredl, J., Holt, W.V., Watson, P.F., Fazeli, A., 2001. Carbohydrate mediation of boar sperm binding to oviductal epithelial cells in vitro. Reproduction 122, 305-315.

Hincke, M.T., Gautron, J., Tsang, C.P., McKee, M.D., Nys, Y., 1999. Molecular cloning and ultrastructural localization of the core protein of an eggshell matrix proteoglycan, ovocleidin-116. The Journal of biological chemistry 274, 32915-32923.

Hincke, M.T., Tsang, C.P., Courtney, M., Hill, V., Narbaitz, R., 1995. Purification and Immunohistochemistry of a Soluble Matrix Protein of the Chicken Eggshell (Ovocleidin 17). Calcified tissue international 56, 578-583.

Hodges, R.D., 1974. The female reproductive system. In: The histology of the fowl. Academic Press, London; New York.

Holm, L., Ekwall, H., Wishart, G.J., Ridderstrale, Y., 2000. Localization of calcium and zinc in the sperm storage tubules of chicken, quail and turkey using X-ray microanalysis. Journal of Reproduction and Fertility 118, 331-336.

Holm, L., Ridderstrale, Y., 1998. Localization of carbonic anhydrase in the sperm-storing regions of the turkey and quail oviduct. The Histochemical journal 30, 481-488. 
Holm, L., Ridderstrale, Y., Knutsson, P.G., 1996. Localisation of carbonic anhydrase in the sperm storing regions of the domestic hen oviduct. Acta anatomica 156, 253-260.

Holm, L., Wishart, G.J., 1998. The effect of $\mathrm{pH}$ on the motility of spermatozoa from chicken, turkey and quail. Anim Reprod Sci 54, 45-54.

Holt, W.V., 2011. Mechanisms of sperm storage in the female reproductive tract: an interspecies comparison. Reproduction in domestic animals $=$ Zuchthygiene 46 Suppl 2, 68-74.

Huang, A., Isobe, N., Obitsu, T., Yoshimura, Y., 2016. Expression of lipases and lipid receptors in sperm storage tubules and possible role of fatty acids in sperm survival in the hen oviduct. Theriogenology 85, 1334-1342.

Kadirvel, G., Machado, S.A., Korneli, C., Collins, E., Miller, P., Bess, K.N., Aoki, K., Tiemeyer, M., Bovin, N., Miller, D.J., 2012. Porcine sperm bind to specific 6-sialylated biantennary glycans to form the oviduct reservoir. Biol Reprod 87, 147.

Lakshminarayanan, R., Joseph, J.S., Kini, R.M., Valiyaveettil, S., 2005. Structure-function relationship of avian eggshell matrix proteins: a comparative study of two major eggshell matrix proteins, ansocalcin and OC-17. Biomacromolecules 6, 741-751.

Lefebvre, R., Lo, M.C., Suarez, S.S., 1997. Bovine sperm binding to oviductal epithelium involves fucose recognition. Biol Reprod 56, 1198-1204.

Mann, K., 1999. Isolation of a glycosylated form of the chicken eggshell protein ovocleidin and determination of the glycosylation site. Alternative glycosylation/phosphorylation at an N-glycosylation sequon. FEBS letters 463, 12-14.

Mann, K., Olsen, J.V., Macek, B., Gnad, F., Mann, M., 2007. Phosphoproteins of the chicken eggshell calcified layer. Proteomics 7, 106-115.

Mann, K., Siedler, F., 1999. The amino acid sequence of ovocleidin 17, a major protein of the avian eggshell calcified layer. Biochem Mol Biol Int 47, 997-1007.

Mann, K., Siedler, F., 2004. Ostrich (Struthio camelus) eggshell matrix contains two different C-type lectin-like proteins. Isolation, amino acid sequence, and posttranslational modifications. Biochimica et biophysica acta 1696, 41-50.

Mann, K., Siedler, F., 2006. Amino acid sequences and phosphorylation sites of emu and rhea eggshell C-type lectin-like proteins. Comparative biochemistry and physiology. Part B, Biochemistry \& molecular biology 143, 160-170.

Marie, P., Labas, V., Brionne, A., Harichaux, G., Hennequet-Antier, C., Nys, Y., Gautron, J., 2015. Quantitative proteomics and bioinformatics analysis provide new insight into protein function during avian eggshell biomineralization. Journal of proteomics 113, 178-193.

Nakano, T., Ikawa, N., Ozimek, L., 2002. Galactosaminoglycan composition in chicken eggshell. Poult Sci 81, 709-714.

Nimtz, M., Conradt, H.S., Mann, K., 2004. LacdiNAc (GalNAcbeta1-4GlcNAc) is a major motif in N-glycan structures of the chicken eggshell protein ovocleidin-116. Biochimica et biophysica acta 1675, 71-80.

Nys, Y., Zawadzki, J., Gautron, J., Mills, D., 1991. Whitening of Brown-Shelled Eggs: Mineral Composition of Uterine Fluid and Rate pf Protoporphyrin Deposition. Poultry Science, 1236-1245.

Panheleux, M., Bain, M., Fernandez, M.S., Morales, I., Gautron, J., Arias, J.L., Solomon, S.E., Hincke, M., Nys, Y., 1999. Organic matrix composition and ultrastructure of eggshell: a comparative study. Br Poult Sci 40, 240-252.

Reyes-Grajeda, J.P., Moreno, A., Romero, A., 2004. Crystal structure of ovocleidin-17, a major protein of the calcified Gallus gallus eggshell: implications in the calcite mineral growth pattern. The Journal of biological chemistry 279, 40876-40881. 
604

605

606

607

608

609

610

611

612

613

614

615

616

617

618

619

620

621

622

623

624

625

626

627

628

629

630

631

632

633

634

635

636

637

638

639

640

641

642

643

644

Richardson, K.C., 1935. The Secretory Phenomena in the oviduct of the fowl, Including the Process of Shell Formation Examined by the Microincineration Technique. Philosophical transactions of the Royal Society of London. Series B, Biological sciences 225, 149-195.

Rose, M.L., Hincke, M.T., 2009. Protein constituents of the eggshell: eggshell-specific matrix proteins. Cellular and molecular life sciences : CMLS 66, 2707-2719.

Sauveur, B., de Reviers, M., 1988. Reproduction and egg production in poultry. Institut National de la Recherche Agronomique, Paris.

Suarez, S.S., 2001. Carbohydrate-mediated formation of the oviductal sperm reservoir in mammals. Cells, tissues, organs 168, 105-112.

Suarez, S.S., 2008. Regulation of sperm storage and movement in the mammalian oviduct. The International journal of developmental biology 52, 455-462.

Suarez, S.S., 2016. Mammalian sperm interactions with the female reproductive tract. Cell Tissue Res 363, 185-194.

Sun, C., Xu, G., Yang, N., 2013. Differential label-free quantitative proteomic analysis of avian eggshell matrix and uterine fluid proteins associated with eggshell mechanical property. Proteomics 13, 3523-3536.

Tingari, M.D., Lake, P.E., 1973. Ultrastructural studies on the uterovaginal sperm-host glands of the domestic hen, Gallus domesticus. J Reprod Fertil 34, 423-431.

Trowbridge, J.M., Gallo, R.L., 2002. Dermatan sulfate: new functions from an old glycosaminoglycan. Glycobiology 12, 117R-125R.

Van Krey, H.P., Ogasawara, F.X., Pangborn, J., 1967. Light and electron microscopic studies of possible sperm gland emptying mechanisms. Poult Sci 46, 69-78.

Wagner, A., Ekhlasi-Hundrieser, M., Hettel, C., Petrunkina, A., Waberski, D., Nimtz, M., Topfer-Petersen, E., 2002. Carbohydrate-based interactions of oviductal sperm reservoir formation-studies in the pig. Molecular reproduction and development 61, 249-257.

Waqas, M.Y., Yang, P., Ahmed, N., Zhang, Q., Liu, T., Li, Q., Hu, L., Hong, C., Chen, Q., 2016. Characterization of the ultrastructure in the uterovaginal junction of the hen. Poult Sci 95, 2112-2119.

Wellman-Labadie, O., Lakshminarayanan, R., Hincke, M.T., 2008. Antimicrobial properties of avian eggshell-specific C-type lectin-like proteins. FEBS letters 582, 699-704.

Wishart, G.J., Ashizawa, K., 1987. Regulation of the motility of fowl spermatozoa by calcium and cAMP. J Reprod Fertil 80, 607-611.

Wishart, G.J., Staines, H.J., 1999. Measuring sperm:egg interaction to assess breeding efficiency in chickens and turkeys. Poult Sci 78, 428-436.

Wishart, G.J., Wilson, Y.I., 1999. Temperature-dependent inhibition of motility in spermatozoa from different avian species. Anim Reprod Sci 57, 229-235.

Wong, A., Albright, S.N., Giebel, J.D., Ram, K.R., Ji, S., Fiumera, A.C., Wolfner, M.F., 2008. A role for Acp29AB, a predicted seminal fluid lectin, in female sperm storage in Drosophila melanogaster. Genetics 180, 921-931. 
646 Figure 1. Egg fertility in hens $F+(n=28)$ (black bars) and $F-(n=27)$ (white bars) during the 647 first, second and third week after artificial insemination of two $200 \times 10^{6}$ spermatozoa per hen 648 performed on two consecutive days at 45 weeks of age. Data are expressed as mean \pm SEM. 649 The differences between the mean values of the two lines were evaluated using a Mann650 Whitney test. Values differed. $* \mathrm{p}<0.01 ; * * \mathrm{p}<0.001$.

651

652

Figure 2. OC116, OCX36 and OC17 amounts in UF from F+ and F- hens. (A) Representative profiles of OC116, OCX36 and OC17 amounts in UF from F+ and F- hens. (B) Quantitative analysis of OC-116, OCX36 and OC17 amounts in UF from F+ $(n=4)$ and F- hens $(n=4)$ without AI or $24 \mathrm{~h}$ after AI.

Figure 3. Localization of OC116, OC17 and OCX36 proteins using immunohistochemistry: vaginal $(\mathrm{A}, \mathrm{B}, \mathrm{C}, \mathrm{D})$ and uterine $(\mathrm{E}, \mathrm{F}, \mathrm{G}, \mathrm{H})$ sections. No reactivity for OC-116, OC-17 and OCX36 was detected in vagina sections (A-C). OC-116 staining was limited to uterine surface epithelium (D) while OC-17 staining was limited to uterine tubular glands (E), and OCX36 displayed no reactivity in uterus (F). Negative controls for immunohistochemistry demonstrated the absence of unspecific signal in vagina (D) and uterine $(H)$ tissue. Figure is representative of several observations. 1, lumen; mf, mucosa fold. Scale bar: A-B-C-D-E-F-G$\mathrm{H}, 20 \mu \mathrm{m}$.

Figure 4. Immunohistochemistry of OC-116 protein in the UVJ tissue of F- $(\mathrm{A}, \mathrm{B})$ and $\mathrm{F}+$ (C,D) hens having not subjected (A,C) or subjected to AI (B,D). (A) F- epithelial cells from SST as well as UVJ show positive reactivity for OC-116. The lumen of SST is also staining (arrowhead). (B) F- epithelial cells from SST demonstrate a positive signal for OC-116. Insets show the OC-116 signal in the lumen of SST after AI (i, arrowhead). The luminal staining (ii, arrowhead) is in contact with spermatozoa (ii, arrow). (C) F+ SST cells as well as UVJ show 
669

670

671

672

673

674

675

676

677

678

679

680

681

682

683

684

685

686

687

688

689

690

691

692

693

positive reactivity for OC-116. Staining is also observed in the lumen of SST (arrowhead).

(D) While F+ SST epithelial cells are positively stained for OC-116, the SST lumen containing sperm is also stained (arrowhead). A staining of secretion (encircled) projecting outside SST is observed (iii). The aspect of this secretion is granular (iv). OC-116 signal is visualized surrounding resident sperm (arrowhead, v and vi). Presence of OC-116 in the crown region of a substance filling a large SST (arrowhead, vii). Figure is representative of several observations. 1, lumen; SST, sperm storage tubule. Scale bar: A-B-C-D, $20 \mu \mathrm{m}$; insets in: B-C-D.iv-D.v-D.vi, $10 \mu \mathrm{m}$, insets in: D.iii-D.vii, $20 \mu \mathrm{m}$.

Figure 5. Immunohistochemistry of OC-17 protein and calcium staining by Von Kossa's method in the UVJ tissue from F- $(\mathrm{A}, \mathrm{B})$ and $\mathrm{F}+(\mathrm{F}, \mathrm{G})$ hens without $\mathrm{AI}(\mathrm{A}, \mathrm{F})$ and 24 hours after AI (B,G), and in sperm incubated with UF collected from F- (SPZ + UF-) (D, E) and F+ $(\mathrm{SPZ}+\mathrm{UF}+)(\mathrm{I}, \mathrm{J})$ hens. (A, F) No reactivity was observed in UVJ and SST epithelial cells from $\mathrm{F}+$ and $\mathrm{F}$ - hens not subjected to AI. (B, G) SST containing sperm demonstrate no reactivity for OC-17 after AI. Nevertheless, some large SST show OC-17 luminal positive staining (arrowhead, inset in B and inset $\mathrm{i}$ in $\mathrm{G}$ ) which is concomitant with the presence of resident sperm and a positive signal for Von Kossa's staining method (inset ii in G). (C, H) Negative controls for immunohistochemistry in UVJ from F- and F+ hens after insemination. (D, I) Negative controls for immunohistochemistry in sperm incubated with UF from F- and F+ hens. (E, J) No reactivity was detected in sperm incubated with UF collected from F- and $\mathrm{F}+$ hens. Figure is representative of several observations. 1, lumen; SST, sperm storage tubule. Scale bar: A-B-C-D, $20 \mu \mathrm{m}$; insets in: B-D, $20 \mu \mathrm{m}$.

Figure 6. Immunohistochemistry of OCX36 protein in the UVJ tissue from F- (A,B) and F+ (C,D) hens without AI (A,C) and 24 hours after AI (B,D). (A) F- epithelial cells from SST, but not UVJ, were positive for OCX36 immunodetection in hen having not subjected to AI. Inset shows a granular luminal secretion from SST, positive for OCX36 (i and ii). (B) F- SST 
694

695

696

697

698

699

700

701

702

703

704

705

706

707

708

709

710

711

712

713

714

715

716

717

718

epithelial cells display positive signal for OCX36 after AI. SST lumen was also positive for OCX36 (arrowhead), and resident sperm (arrow) is surrounded by SST secretion positive for OCX36 (arrowhead). (C) F+ SST epithelial cells as well as lumen (inset) display positive reactivity for OCX36. (D) In SSTs filled of spermatozoa, SST epithelial cells were homogeneously positive for OCX36 after AI. Figure is representative of several observations. 1, UVJ lumen; SST, sperm storage tubule. Scale bar: A-B-C-D, $20 \mu \mathrm{m}$; insets in: A-D, $10 \mu \mathrm{m}$.

Figure 7. Staining of vagina $(A, B, C, D)$ and uterus $(E, F, G, H)$ tissue incubated with ECL $(\mathrm{A}, \mathrm{D})$, SBA $(\mathrm{B}, \mathrm{E})$ and WGA $(\mathrm{C}, \mathrm{F})$ lectins. (A) Mucosa from vagina demonstrates ECL positive reactivity. Inset shows the granular aspect of the ECL staining in some epithelial cells of vaginal mucosa. (B) Mucosa from vagina displays no reactivity for SBA except in lymphocytes of the loose connective tissue. (C) Surface epithelium from vagina is positive for WGA immunodetection. Inset shows the apical and the supranuclear WGA staining in cells. (D) Negative control for lectin histochemistry in vagina. (E) Uterine mucosa is positive for ECL immunodetection. Inset focalizes on the apical signal observed in surface epithelial cells and tubular gland cells (arrowhead). (F) No reactivity for SBA is observed in uterine mucosa, except in lymphocytes of the loose connective tissue. (G) Apical WGA staining of uterine surface epithelial and tubular gland cells (arrowhead) are observed. (H) Negative control for lectin histochemistry in uterus. Figure is representative of several observations. 1, lumen; mf, mucosal fold. Scale bar: A-B-C-D-E-F-G-H, $50 \mu \mathrm{m}$; insets in: A-C-E-G, $10 \mu \mathrm{m}$.

Figure 8. Staining of GlcNAc containing glycans by WGA lectin in the UVJ tissue of F$(A, B)$ and $F+(C, D)$ hens having not been subjected $(A, C)$ or subjected to AI (24h: B,D). (A) Intracellular staining is detected in the F- UVJ surface epithelial cells as well as in the transition zone with SST cells. (B) After AI, apical signal is localized into F- UVJ surface epithelium and SST cells (inset). (C) While WGA staining is restricted to apical part of F+ UVJ surface epithelial cells, an intense staining in the supranuclear part of SST cells is 
observed in hens not subjected to AI (inset). (D) After AI, intracelular staining is detected in UVJ surface epithelial cells, whereas an intense apical (inset i) and luminal staining (inset ii) are observed inside SST. Figure is representative of several observations. 1, lumen; SST, Sperm Storage Tubule. Scale bar: A-B-C-D, $25 \mu \mathrm{m}$; insets in: A-B-C-D, $25 \mu \mathrm{m}$.

Figure 9. Staining of GalNAc containing glycans by ECL lectin in the UVJ tissue of F- $(A, B)$ and $\mathrm{F}+(\mathrm{C}, \mathrm{D})$ hens having not been subjected $(\mathrm{A}, \mathrm{C})$ or subjected to AI $(24 \mathrm{~h}: \mathrm{B}, \mathrm{D})$. (A) Intracellular staining was limited to some cells of the F- UVJ surface epithelium (inset i), whereas apical staining was observed in SSTs (inset ii) without AI. (B) After AI, the top of UVJ epithelial cilia were stained (arrowheads). Supranuclear staining of some SST cells is observed (encircled). Inset demonstrates the apical (iii) and luminal (iv) staining of SST. (C) Apical staining on surface epithelium and SST cells is observed. (D) Intracellular staining is visualized in SSTs (dot circle), and UVJ surface epithelium (inset vi). Inset $\mathrm{v}$ focuses on apical signal in SST cells. Figure is representative of several observations. 1, Lumen; SST, Sperm Storage Tubule. Scale bar: A-B-C-D, $25 \mu \mathrm{m}$; insets in: A-B-C-D, $25 \mu \mathrm{m}$.

Figure 10. Staining of GalNAc terminating glycans by SBA lectin in the UVJ tissue of F$(A, B)$ and $F+(C, D)$ hens having not been subjected $(A, C)$ or subjected to AI (24h: B,D). (A) Staining was observed in some F- SST cells of the UVJ (encircled) before AI. Inset shows apical staining of SST cells. (B) After AI, intense signals are observed on F- SST apices as well as on the top of UVJ surface epithelial cilia (arrowhead). Insets demonstrate the UVJ surface epithelial cilia staining (inset i, arrowheads) and luminal staining of SST (inset ii). (C) Before AI, supranuclear signal is vizualized in F+ SST cells (encircled). Inset focuses on the supranuclear staining in a SST transversal section. (D) After AI, apical and luminal staining is observed in F+ SST containing resident sperm. Inset shows the intense staining of the top of UVJ cilia (arrowhead). Figure is representative of several observations. 1, Lumen; SST, Sperm Storage Tubule; SPZ, spermatozoa. Scale bar: A-B-C-D, $25 \mu \mathrm{m}$; insets in: A-B-C-D, $25 \mu \mathrm{m}$. 


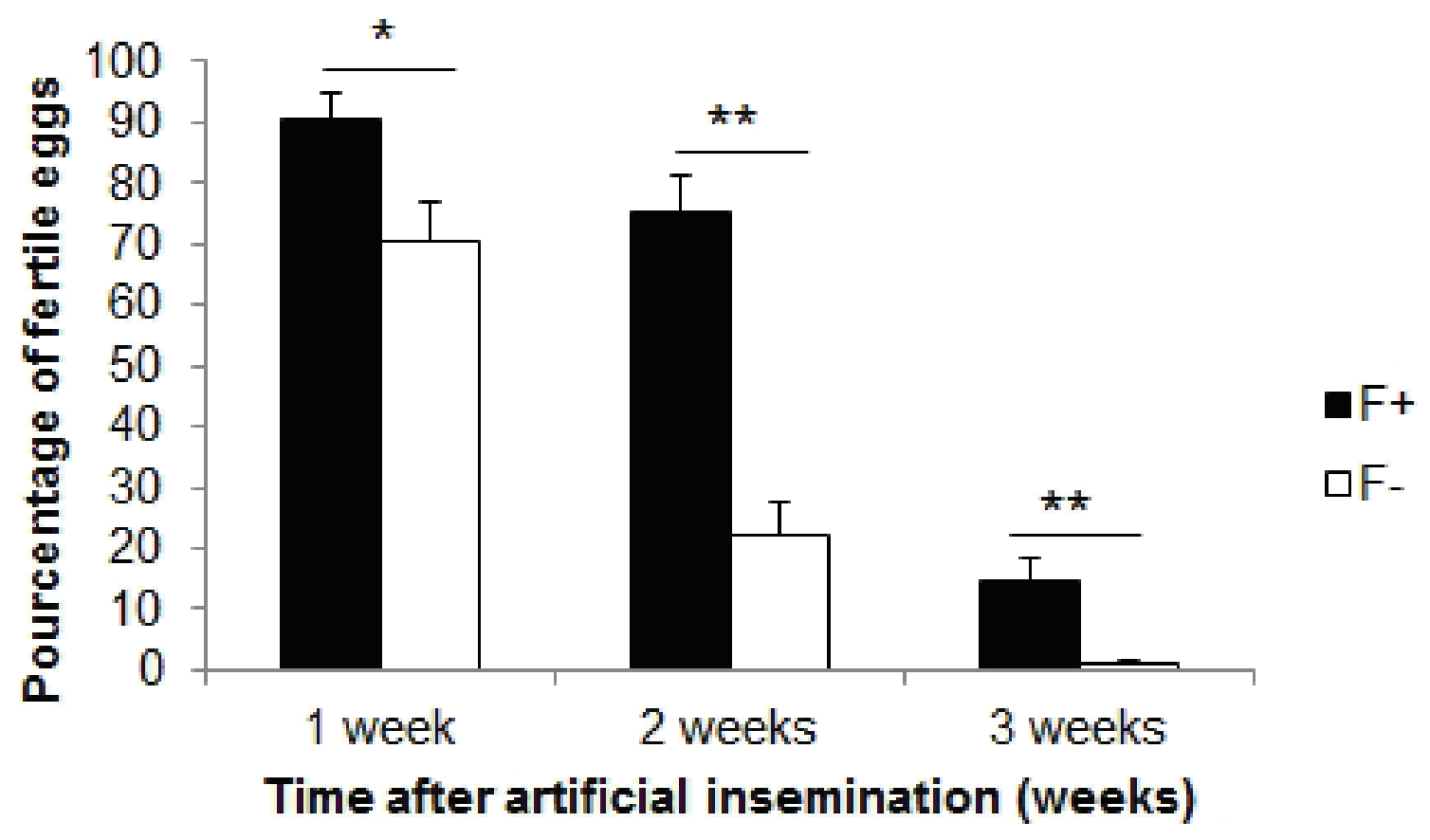


A

\begin{tabular}{lrlll} 
& & F+ F- \\
OC116 & $116 \mathrm{kDa}$ & \\
OCX36 & $36 \mathrm{kDa}$ & \\
OC17 & $17 \mathrm{kDa}$ & \\
\hline
\end{tabular}

B

- OC116 \$OC17 口OCX36

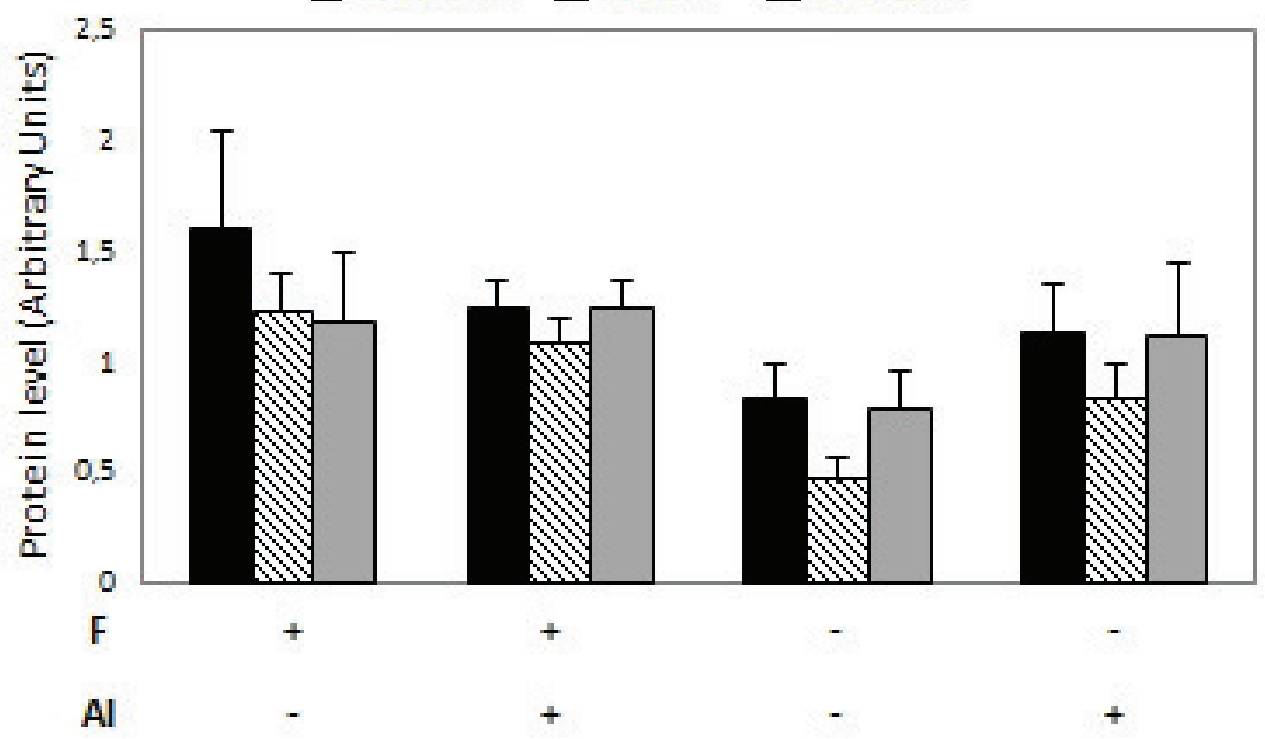



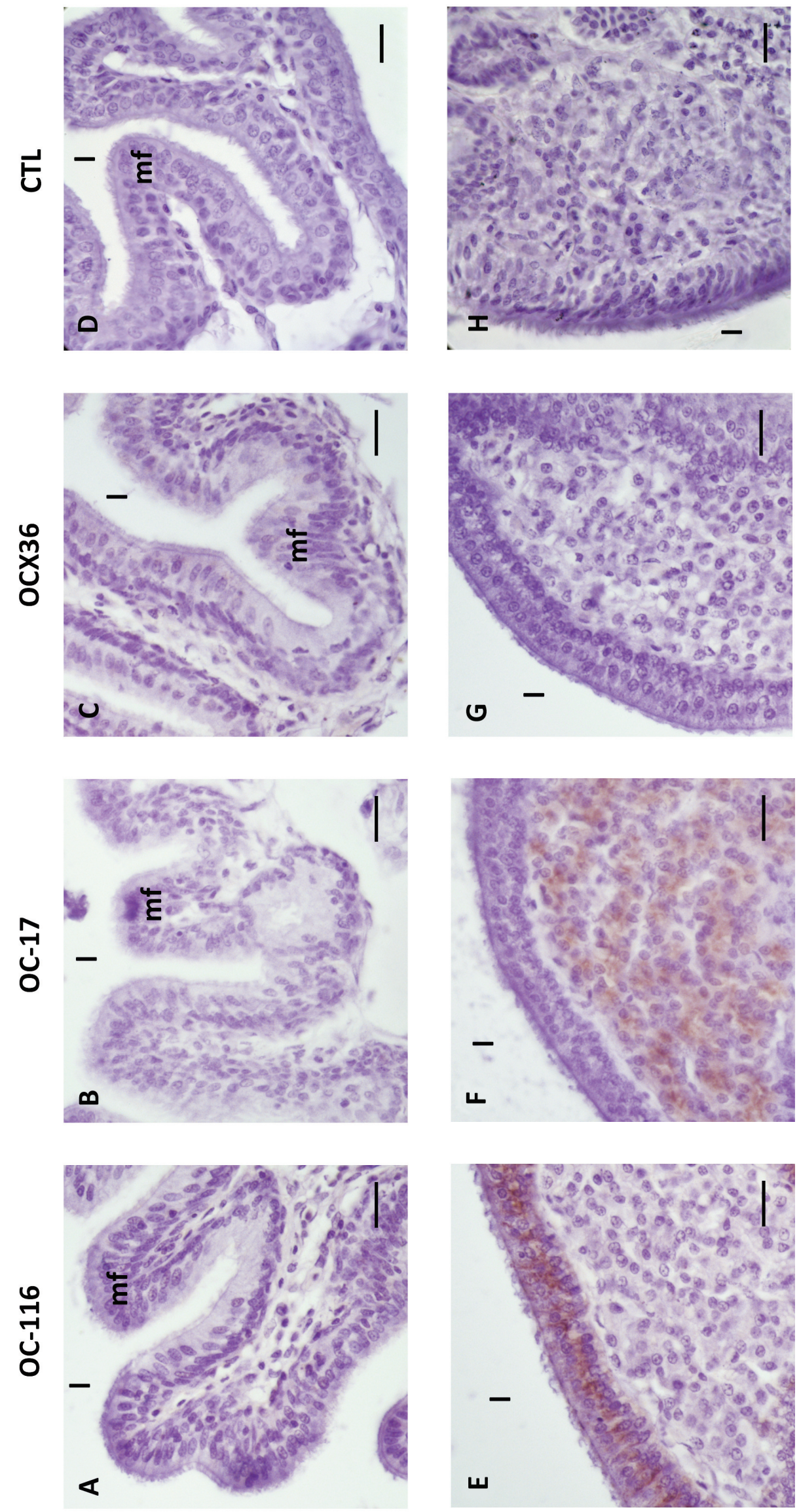

eu!se

snגə子ก 

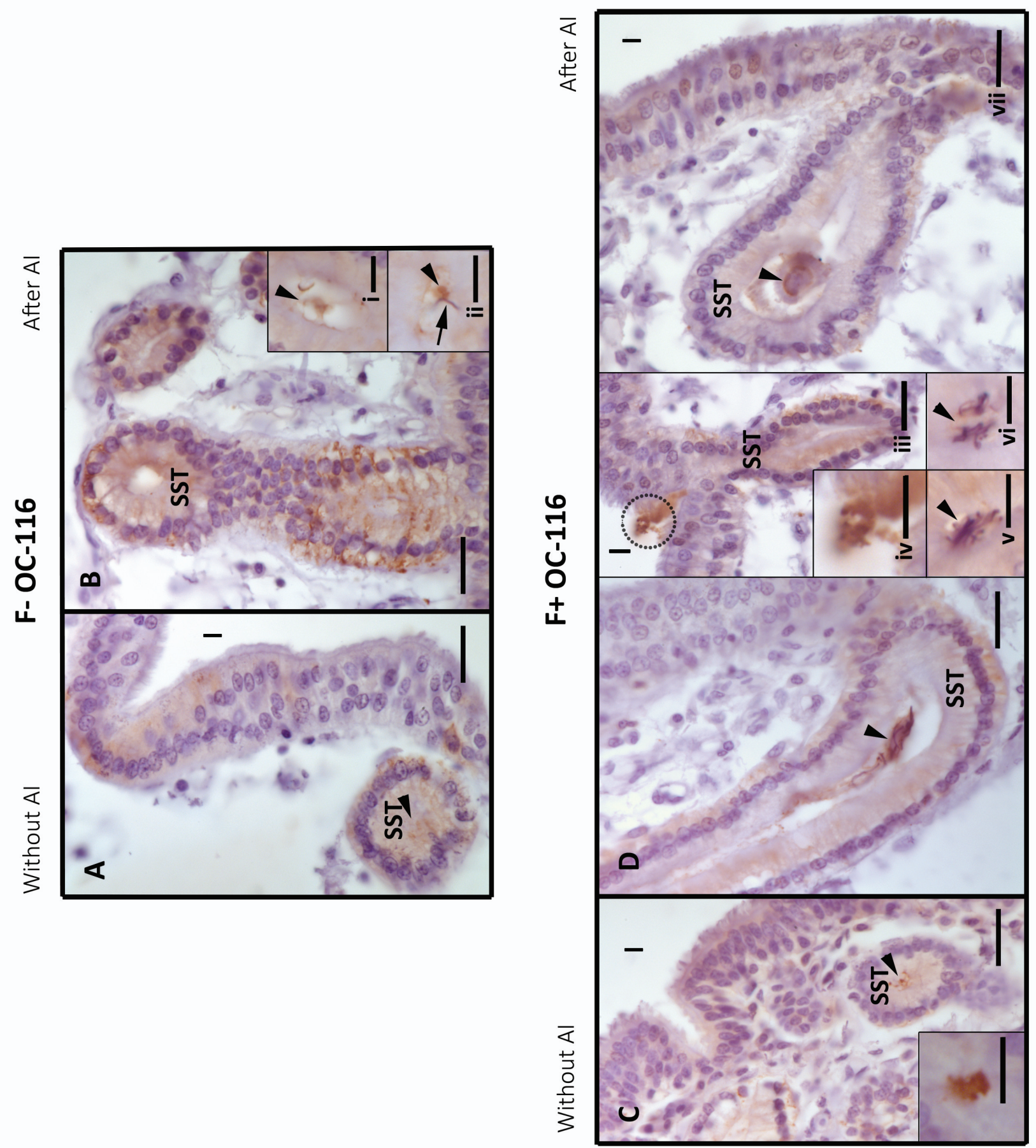

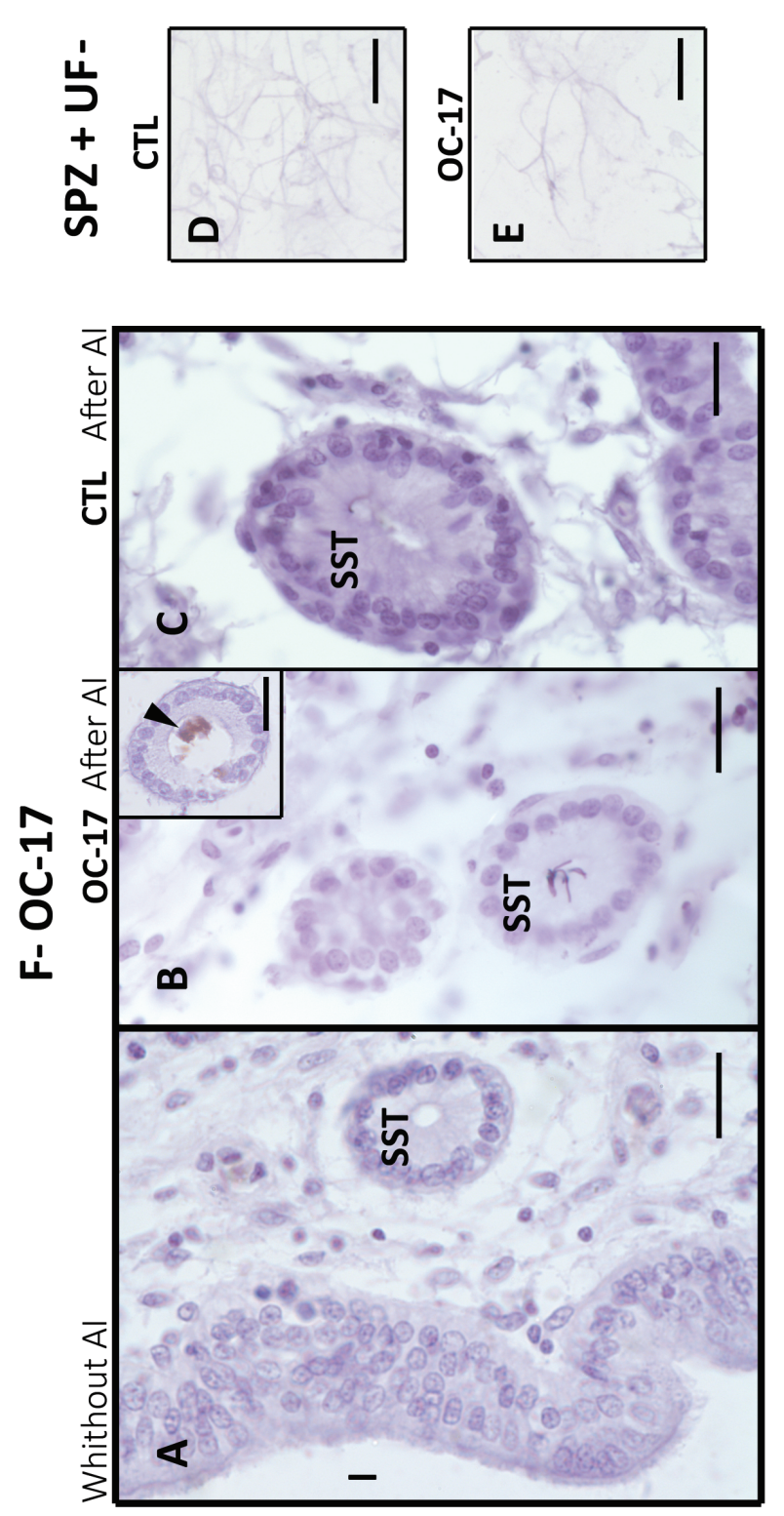
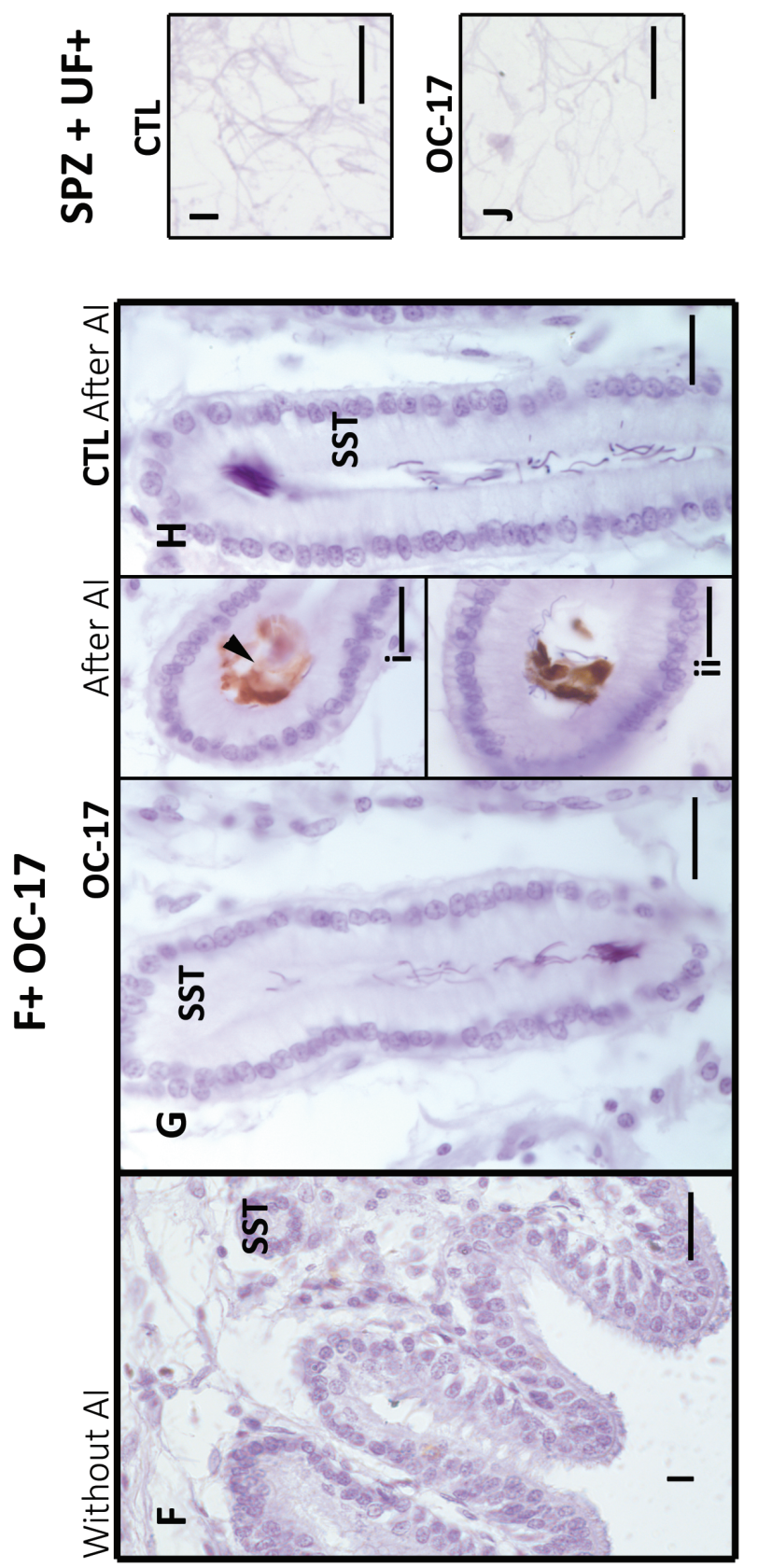
Without Al

F- OCX36

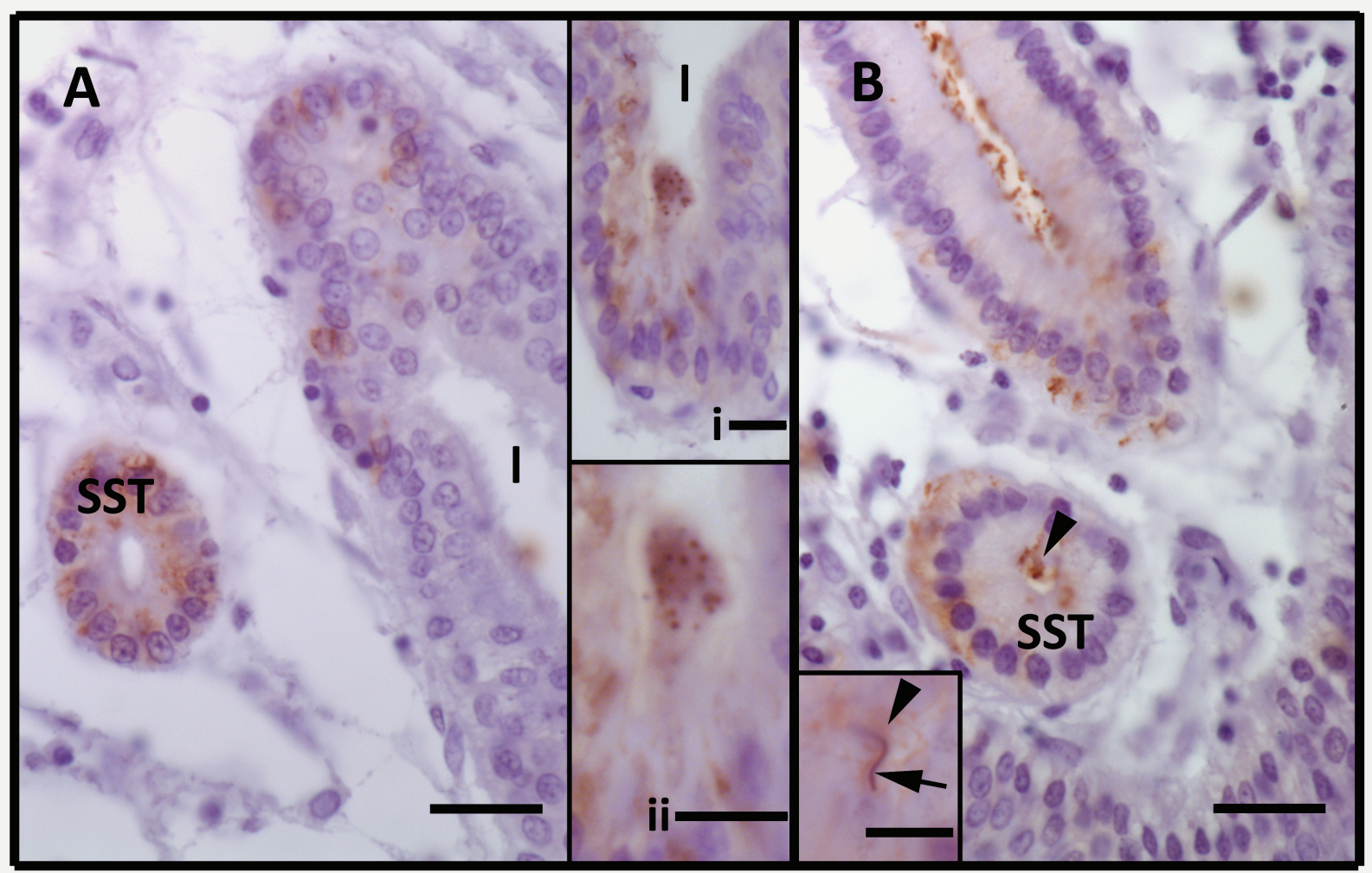

F+ OCX36

Without Al

After Al

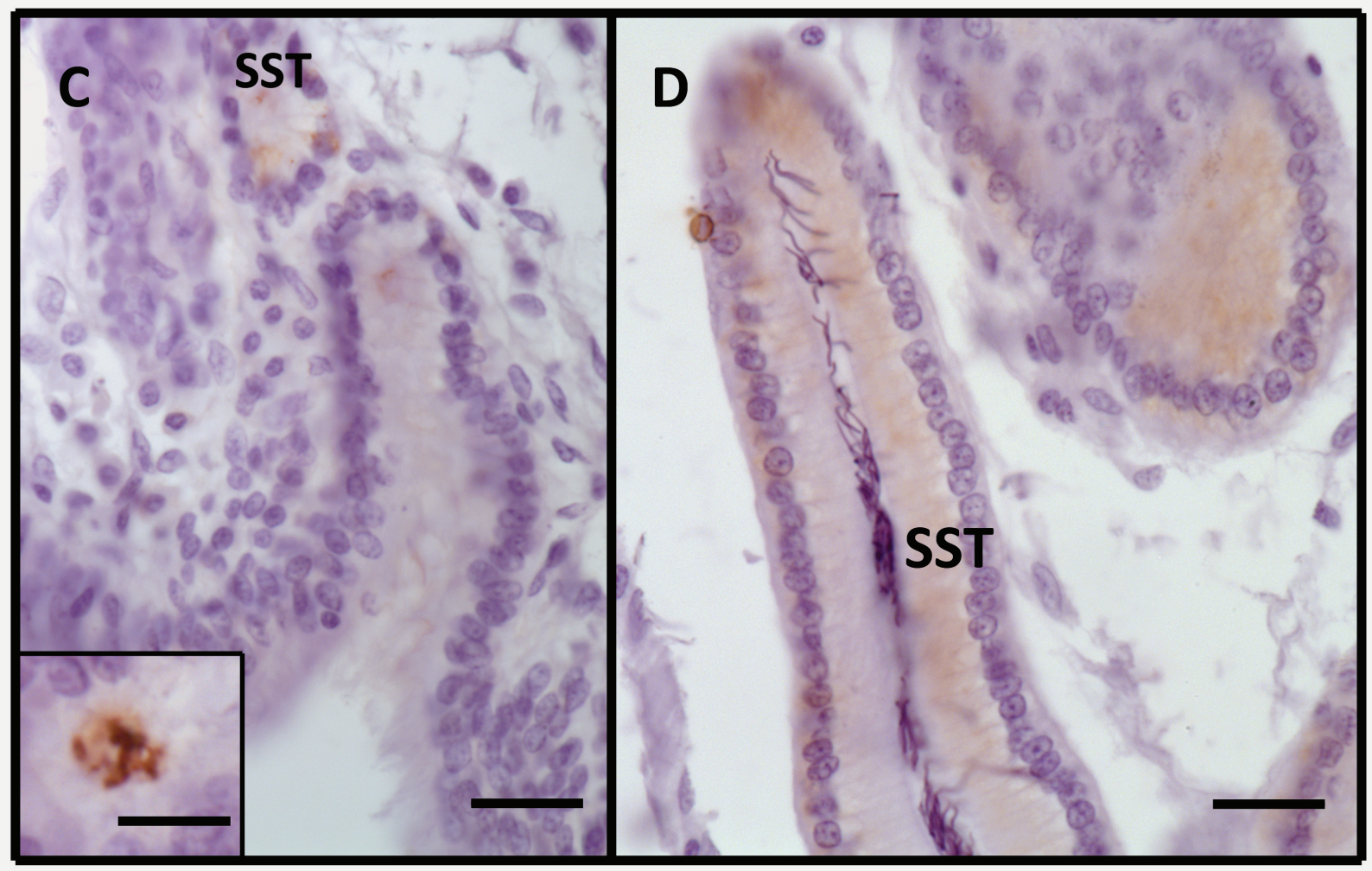



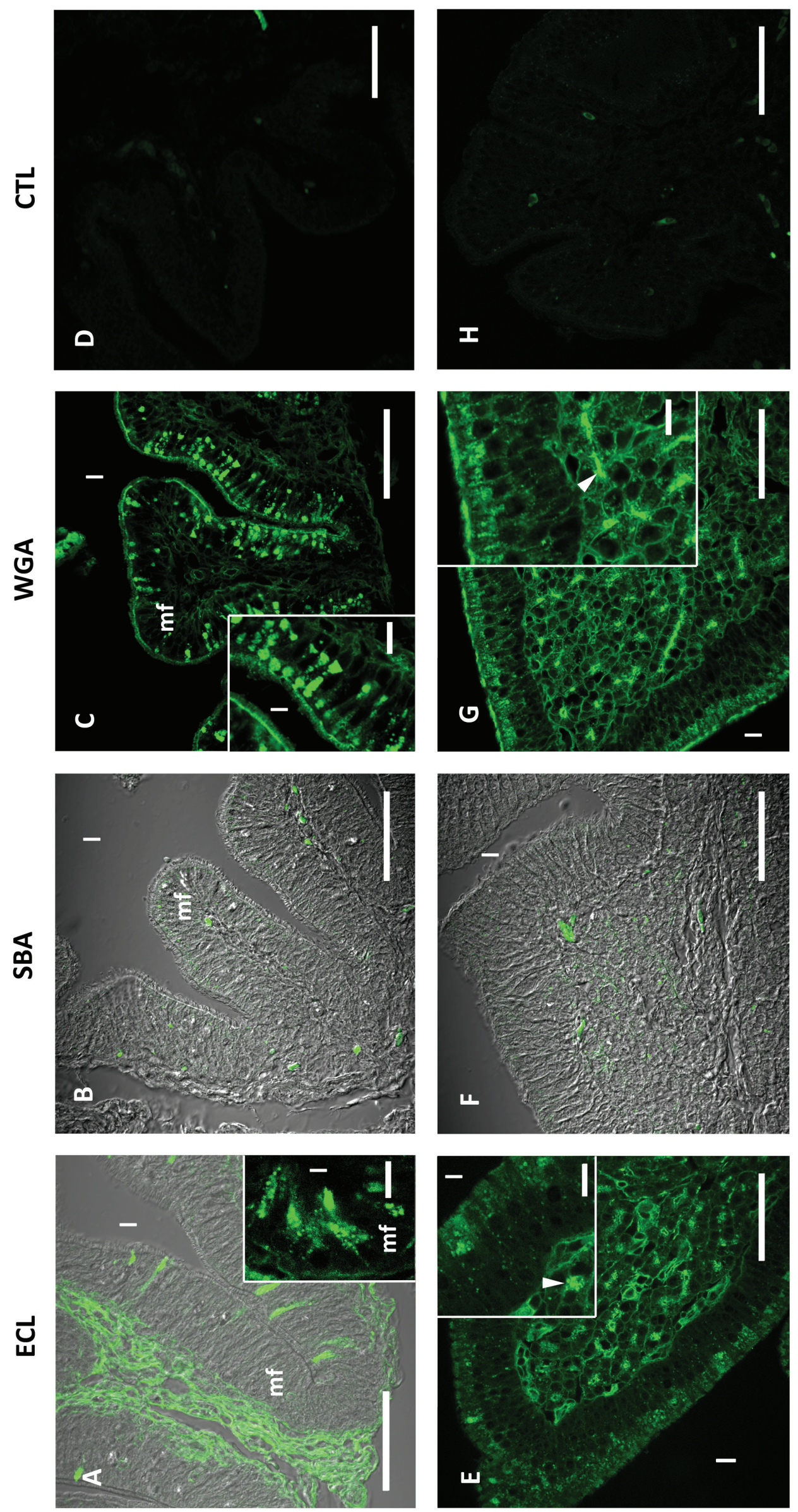

eu!̊sen

snıəzก 

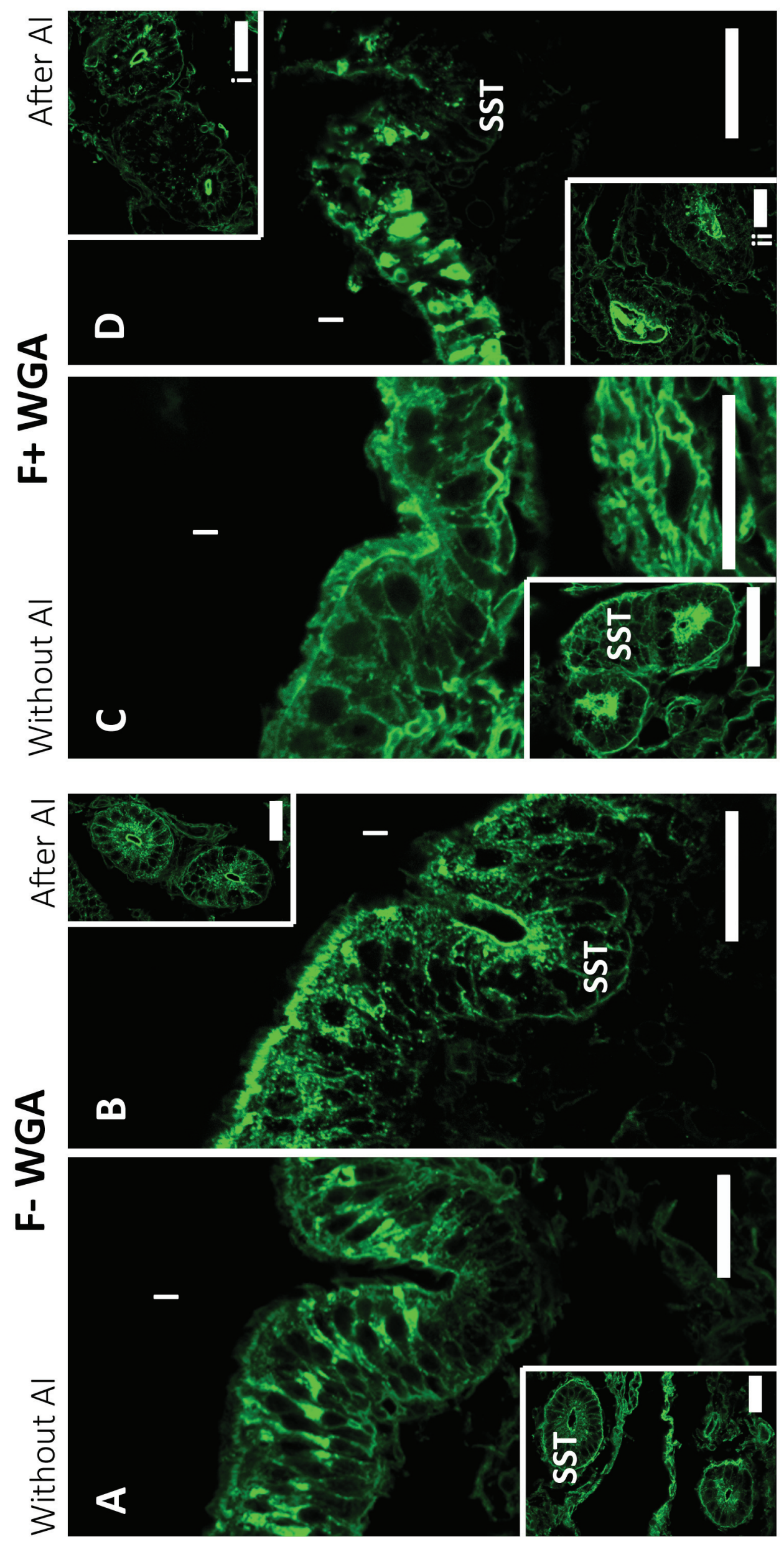

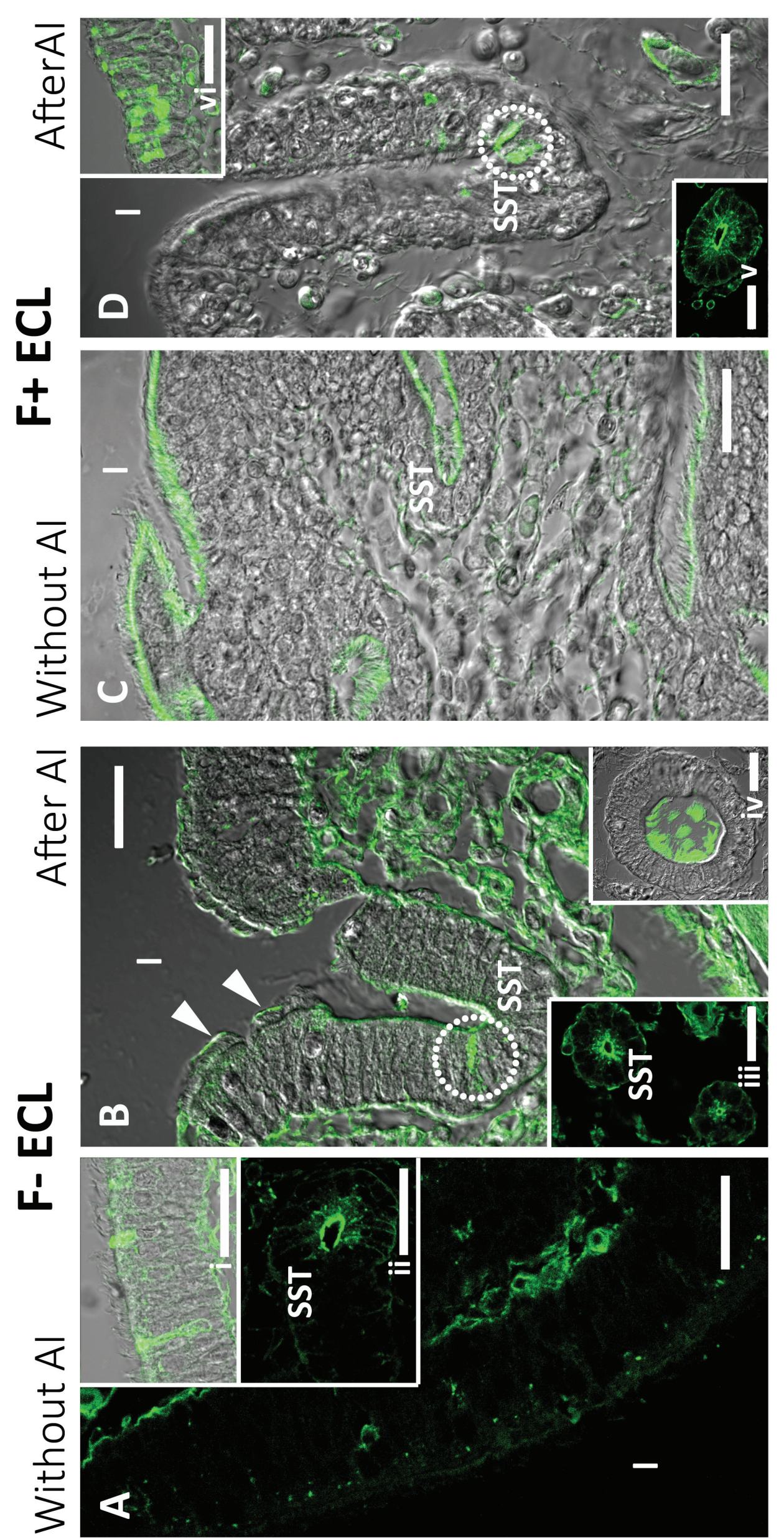

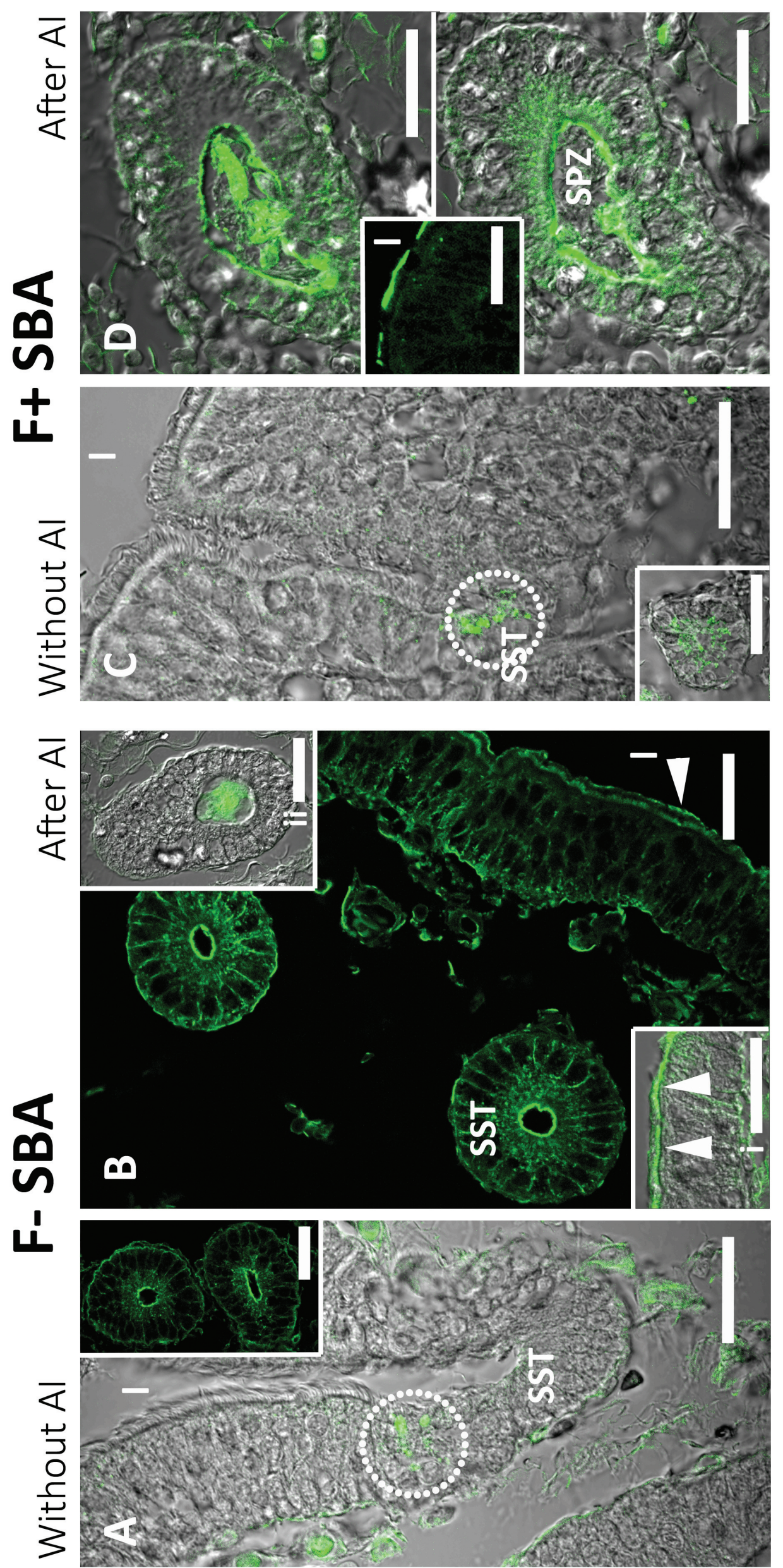


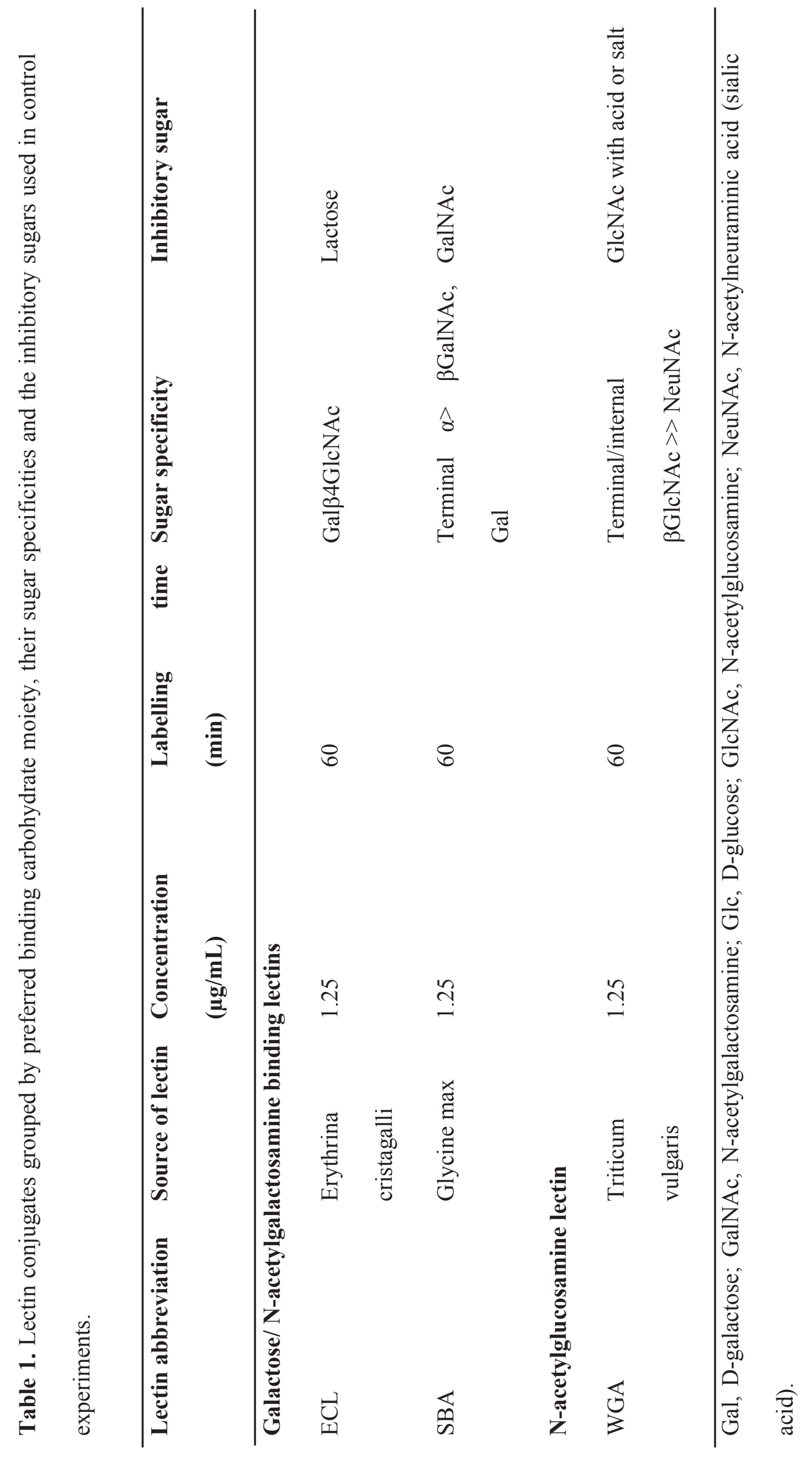




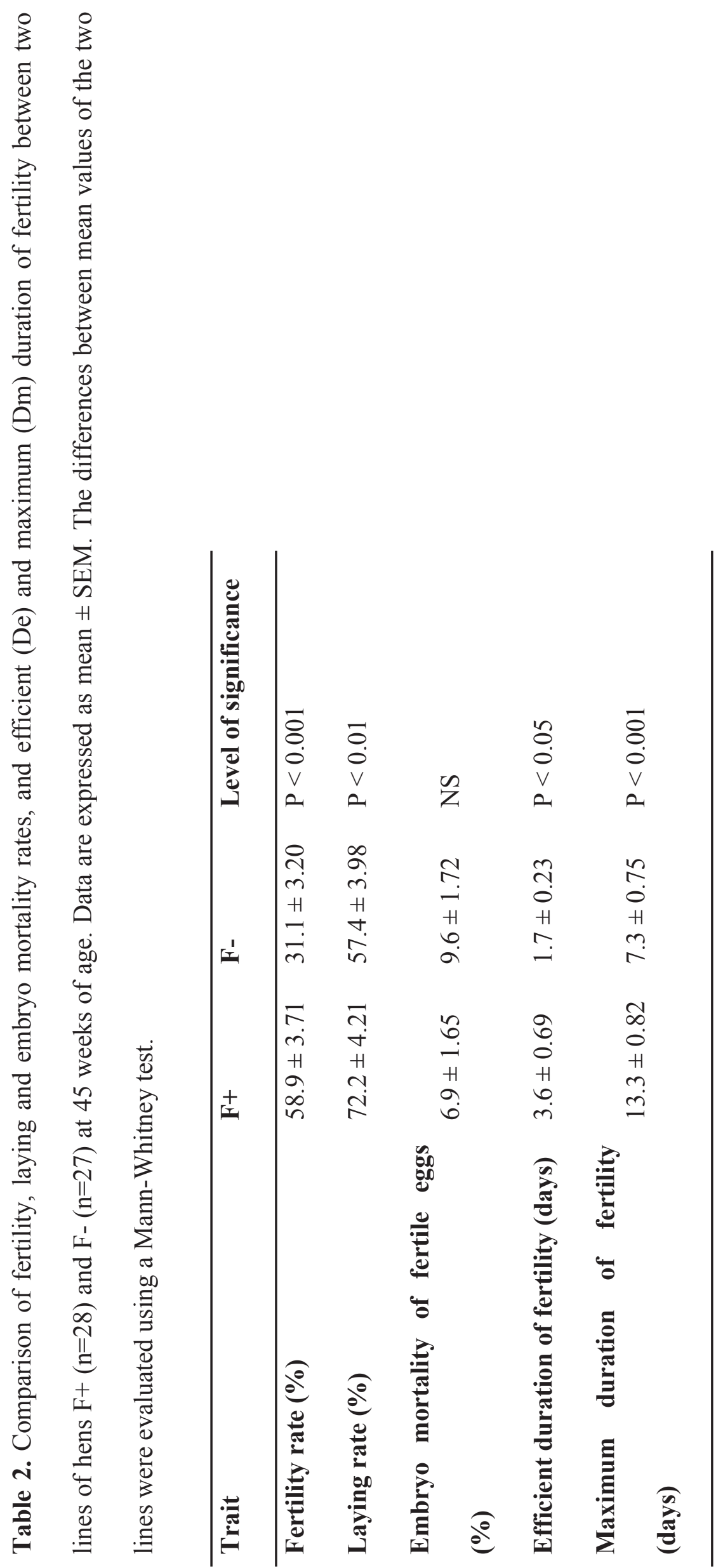




\section{Declaration of interest}

The authors declare no conflict of interest. 